\title{
Burial and exhumation of the western border of the Ukrainian Shield (Podolia): a multi-disciplinary approach
}

\author{
Andrea Schito,* Benedetta Andreucci,† Luca Aldega,\$Sveva Corrado,* Lea Di Paolo,* \\ Massimiliano Zattin, $\uparrow$ Rafal Szaniawski, $\S$ Leszek Jankowski $\uparrow$ and Stefano Mazzoli** \\ * Department of Earth Sciences, University of Roma Tre, Rome, Italy \\ $\dagger$ Department of Geosciences, University of Padua, Padua, Italy \\ $\$$ Department of Earth Sciences, University of Rome "Sapienza", Rome, Italy \\ §Institute of Geophysics, Polish Academy of Science, Warsaw, Poland \\ $₫$ Polish Geological Institute-Carpathian Branch, Cracow, Poland \\ **Department of Earth Sciences, University of Naples "Federico II", Napoli, Italy
}

\begin{abstract}
The Podolia region is located along the western border of the Eastern European Craton, which is also known as Ukrainian Shield. From the Ordovician to the Miocene, this area formed part of an epicontinental basin system. In order to investigate the effects of orogenic cycles occurring along the plate margin, a multi-disciplinary approach was used in this study. Paleotemperature analysis and lowtemperature thermochronometry were combined with stratigraphic data to obtain a burial model for the Paleozoic succession exposed in the study area. Maximum burial for Silurian and Devonian rocks occurred during the Devonian and Early Carboniferous at depths of 4-5 km, as constrained by vitrinite reflectance and illite content in mixed illite-smectite layers. Thermochronometric data indicate that exhumation through the $45-120{ }^{\circ} \mathrm{C}$ temperature range took place between the Late Triassic and the Early Jurassic, and that no significant burial occurred afterwards (temperatures characterising the stratigraphically lowermost units remaining below ca. $60{ }^{\circ} \mathrm{C}$ ). These results point to a major exhumation event coeval with the Cimmerian orogenesis, which took place a few hundreds of kilometres away from the study area. On the other hand, no significant effect of the Alpine orogenesis was recorded, although the collisional front was located $<100 \mathrm{~km}$ from the Podolia region. This work shows how paleothermal and thermochronometric analyses can be successfully integrated with stratigraphic data to reconstruct the burial history, and how the burial history of a basin located on a plate margin can, in some cases, be independent from the distance of the margin from the collisional fronts.
\end{abstract}

\section{INTRODUCTION}

The Podolia region (Southern Ukraine) is located to the east of the Trans European Suture Zone (TESZ), a suture between the weaker and thinner Western European lithosphere, and the thicker and stronger Eastern European Craton (EEC; e.g. Drygant, 2000; Skompski et al., 2008; Małkowski et al., 2009; Fig. 1), in the so-called PeriTornquist margin (i.e. western margin of the EEC). During the Early Paleozoic, and later during the Neogene, this region was part of epicontinental basin systems that extended along the Peri-Tornquist Margin (e.g. Wrona \& Lis, 2012; and references therein). The diagenetic evolution of the Paleozoic strata exposed in this area has been investigated in recent years (Środoń et al., 2013), with

Correspondence: Andrea Schito, Department of Earth Sciences, University of Roma Tre, Largo San Leonardo Murialdo 1, 00146, Rome, Italy. E-mail: andrea.schito@uniroma3.it particular focus on the succession cropping out along the Dniestr River (Huff et al., 2000). Based on X-ray diffraction, K-Ar and apatite fission track data, Środoń et al. (2013) reconstructed the T-t paths for the Lower Paleozoic part of this succession. However, their study did not take into account stratigraphic information and, thus, did not produce a burial model.

In this work, we provide a set of original paleothermal and thermochronometric data that integrate stratigraphic information to constrain the thermal and burial history of the western border of the Ukranian Shield (Figs $1 \mathrm{~b}$ and 2 ). In particular, we combine X-ray diffraction of the inorganic fraction of sediments and organic matter optical analysis with apatite fission-track (AFT) and U-Th/He analyses. These latter two thermochronological methods are characterised by well-established closure temperatures $\left(T_{\mathrm{c}}\right)$ of ca. $110^{\circ} \mathrm{C}$ and $60^{\circ} \mathrm{C}$, respectively (Ketcham et al., 1999; Gautheron et al., 2009; Flowers et al., 2009; Djimbi et al., 2015). Stratigraphic data were used to 

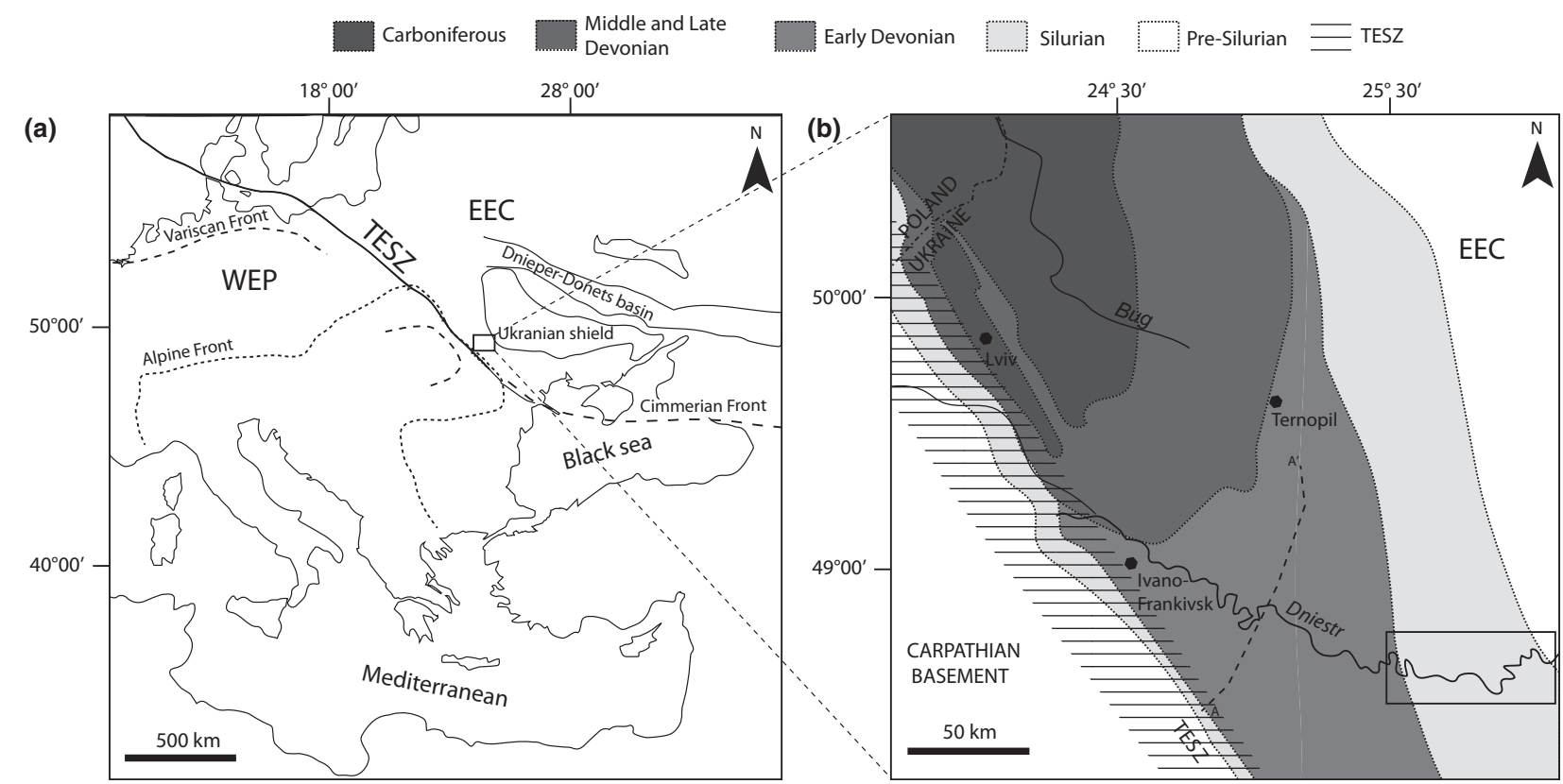

Fig. 1. (a) Simplified sketch map of Europe, showing Variscan, Cimmerian and Alpine fronts; WEP - West European Platform; TESZ- Trans European Suture Zone; EEC - East European Craton. Black box shows location of the Podolia region. (b) Simplified geological map (with post-Palaeozoic cover removed; redrawn after Środoń et al., 2013) showing location of the study area of Fig. 2 (black box) and the line AA' of the section presented in Fig. 3c.

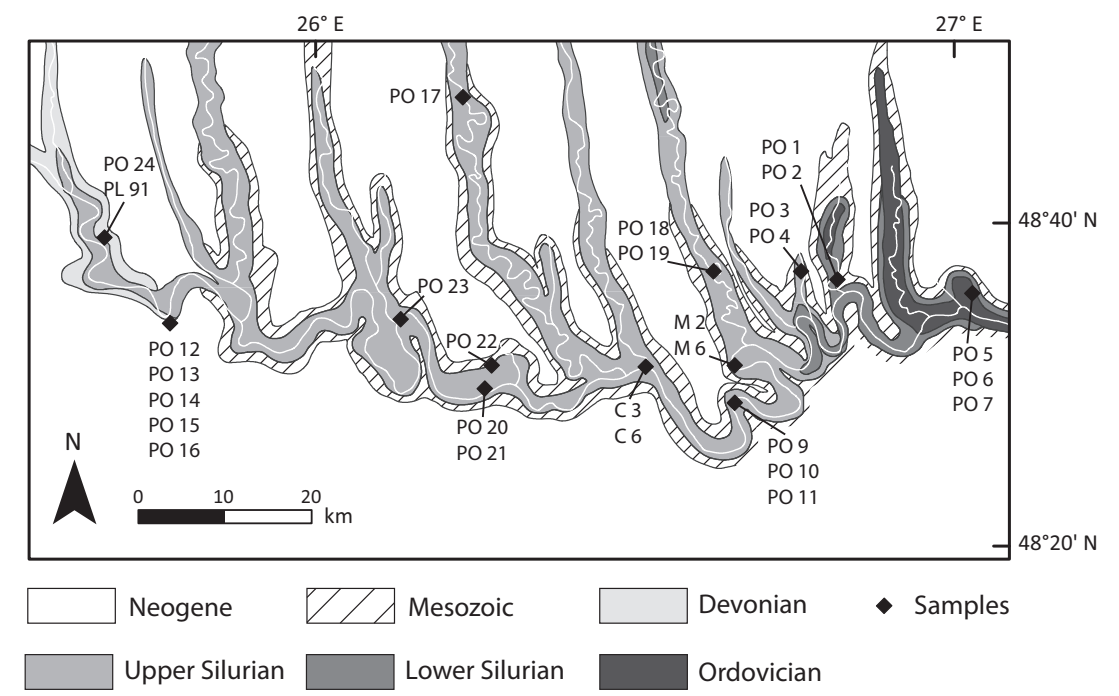

Fig. 2. Geological map of the study area with sample location (Dniestr River path is shown in white).

reconstruct pseudo-wells, allowing us to trace the burial evolution of the basin. The burial and exhumation events that took place in the Podolia epicontinental basin provide information on the tectonic evolution of the margin of the East European Craton and eventually allowed us to evaluate the effects of different orogenic cycles - Variscan, Cimmerian, Alpine - along the plate margin.

\section{Geological setting}

The Ordovician-Silurian succession in Podolia is mainly constituted by shelf facies, consisting of lagoonal, reef and open shelf deposits, with distal facies extending to the west moving towards the TESZ. During the Late Silurian and the Early Devonian, slope and basin facies progressively tend to prevail on shelf facies, while in the late Early Devonian the continental margin progrades westward and a continental sedimentary environment (i.e. that of the "Old Red Sandstones") establishes throughout the Peri-Tornquist margin. Carboniferous and Permian deposits occur farther to the NW (Buła \& Habryn, 2011).

The outcropping sedimentary succession is characterised by three angular unconformities, representing periods of uplift and erosion. A first unconformity separates Lower Silurian deposits from the underlying Ordovician units (e.g. Wrona \& Lis, 2012). A second one 
A. Schito et al.

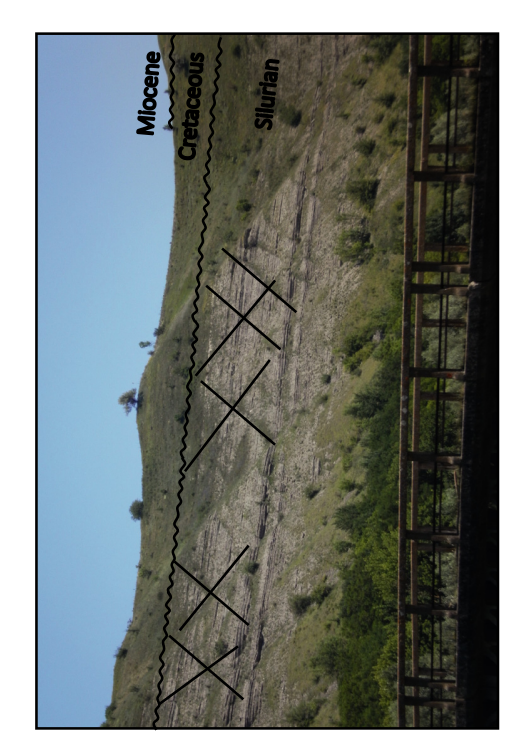

a

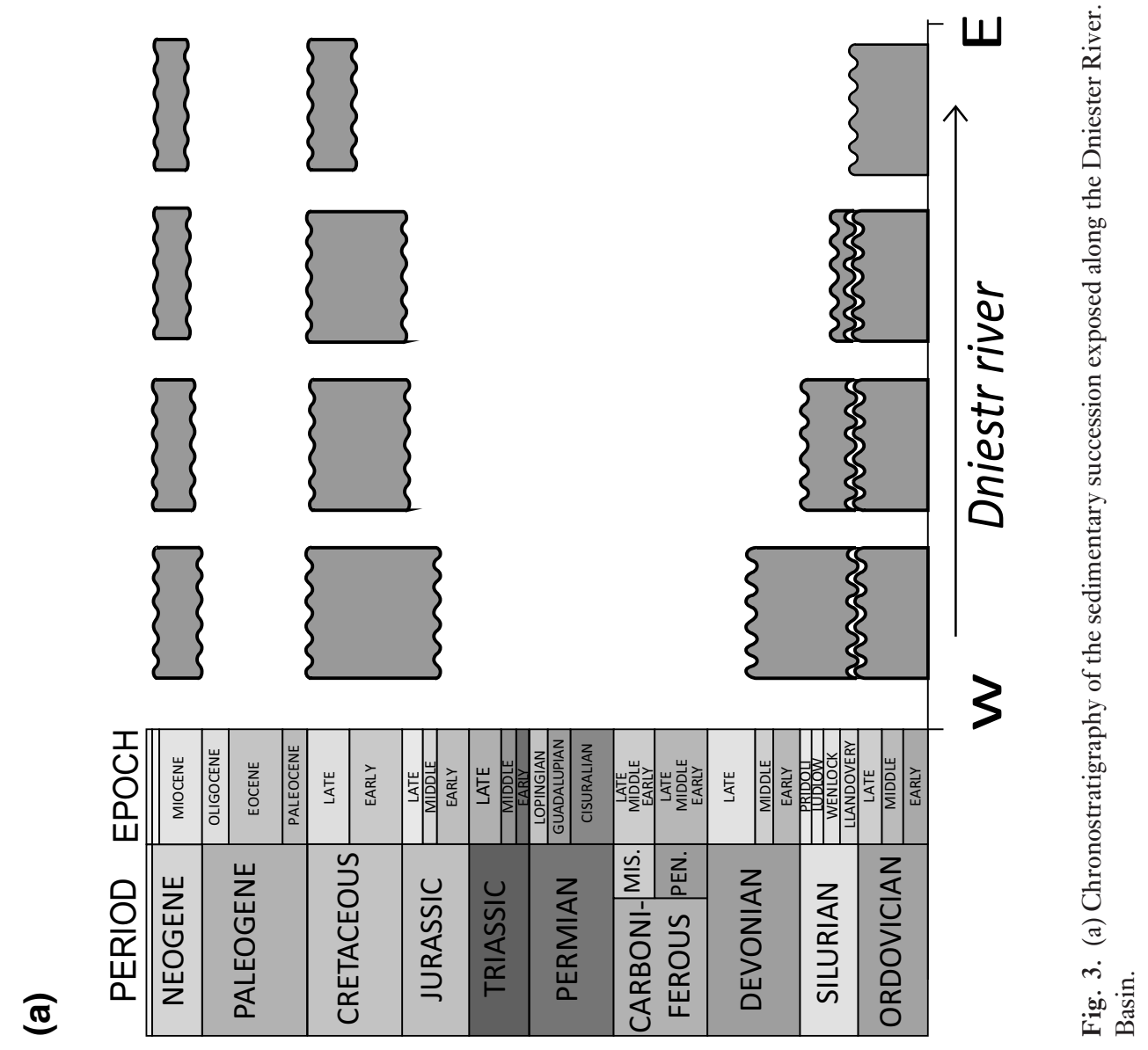


separates Middle-Upper Jurassic strata from the underlying upper Lower Devonian beds (in the western part of the basin) and Upper Ordovician deposits (to the east, Fig. 3a). Finally, a third unconformity is located between the Miocene deposits and the underlying Middle-Upper Cretaceous strata (Fig. 3a-b).

Figure $3 \mathrm{c}$ represents a section located to the northwest of our study area, going from the Carpathian foredeep (e.g. Castelluccio et al., 2016; and references therein) to the L'viv-Volyn Basin. This latter is the Ukrainian part of the NW-trending Lublin Basin in Poland that developed in the late Visean (Sachsenhofer \& Koltun, 2012). The section shows how the Paleozoic-Mesozoic stratigraphic gap tapers off towards the TESZ (i.e. westwards) as a result of the westward increase in the Paleozoic sedimentary thickness and the progressive onlap of Mesozoic sediments on the SW-ward gently tilted Paleozoic strata of the Peri-Tornquist margin to the east (e.g. Kurovets \& Koltun, 2012). Mesozoic sediments onlapping against the Lower Devonian deposits consist of Middle Jurassic continental conglomerates passing upward to Upper Jurassic to Cenomanian lagoonal and open shelf sediments. Middle-Upper Miocene marine sediments onlap against the Mesozoic sediments of the Peri-Tornquist margin. Isolated remnants of Upper Eocene quartz-glauconitic sands occur in the easternmost portion of the Podolia region, indicating that erosion of the Paleogene deposits occurred in Oligocene-Early Miocene times. Continental conditions established during Pliocene-Quaternary times.

The unconformities within the Podolian succession reveal that this epicontinental basin underwent periods of extensive uplift and erosion, most likely related to geodynamic processes involving the plate margin. The collisional events that occurred along the craton edge since the establishment of the Podolia sedimentary basin on the Peri-Tornquist margin are related with: (i) Caledonian (Ordovician-Early Devonian), (ii) Variscan (DevonianCarboniferous), (iii) Cimmerian (Triassic-Jurassic) and (iv) Alpine (Late Cretaceous-Tertiary) orogeny. Figure 1a shows the thrust fronts of these orogens.

\section{MATERIALS AND METHODS}

X-ray diffraction and organic matter optical analyses allowed us to obtain a robust dataset for constraining the maximum burial experienced by studied succession. Apatite fission track and apatite (U-Th/He) dating were used to trace the cooling history of the sedimentary succession through their partial retention zones (PRZ; i.e. the range of temperatures through which a thermochronometric system passes from an open to a closed system state, e.g. Reiners \& Brandon, 2006). The thermochronometers used in this work have PRZ in the range of ca. $120-45{ }^{\circ} \mathrm{C}$ (Reiners \& Brandon, 2006). Coupling indicators of maximum burial and thermochronometers is important to substantially reduce the number of acceptable thermal and burial histories for the basin (Aldega et al., 2011; Carlini
Table 1. Sampling location, stratigraphic age and lithology

\begin{tabular}{lllll}
\hline Sample & Latitude & Longitude & Age & Lithology \\
\hline Po24 & 48,71967 & 25,63824 & Lower Devonian & Calcarenite \\
Po15 & 48,63022 & 25,73717 & Lower Devonian & Pelite \\
Po16 & 48,63022 & 25,73717 & Lower Devonian & Cherty-Marl \\
Po13 & 48,63164 & 25,73578 & Lower Devonian & Marl \\
Po12 & 48,63164 & 25,73578 & Lower Devonian & Marl \\
Po23 & 48,61614 & 26,08917 & Lower Devonian & Marly-Pelite \\
Po20 & 48,53795 & 26,23940 & Upper Pridoli & Marl \\
Po17 & 48,84389 & 26,21535 & Pridoli & Pelite \\
Po10 & 48,50578 & 26,60647 & Ludlovian & Siltite \\
Po11 & 48,50578 & 26,60647 & Ludlovian & Siltite \\
Po19 & 48,64827 & 26,60233 & Ludlovian & Pelite \\
Po18 & 48,64825 & 26,60266 & Ludlovian & Marly-Pelite \\
Po4 & 48,63841 & 26,73205 & Wenlockian & Pelite \\
Po3 & 48,63841 & 26,73205 & Llandoverian & Coarse-Siltite \\
Po2 & 48,63829 & 26,78214 & Llandoverian & Silty-Pelite \\
Po1 & 48,63829 & 26,78214 & Llandoverian & Siltite \\
Po7 & 48,59098 & 26,99714 & Ordovician & Pelite \\
Po8 & 48,59092 & 26,99718 & Ordovician & Siltite \\
C3 & 48,54468 & 26,47996 & Silurian & Bentonite \\
C6 & 48,54468 & 26,47996 & Silurian & Bentonite \\
M2 & 48,54649 & 26,63239 & Silurian & Bentonite \\
M6 & 48,54649 & 26,63239 & Silurian & Bentonite \\
PL91 & 48,71967 & 25,63824 & Lower Devonian & Calcarenite \\
\hline & & & &
\end{tabular}

et al., 2013; Caricchi et al., 2015; di Paolo et al., 2014; Invernizzi et al., 2008; Corrado et al., 2009, 2010a,b; Schito et al., 2016).

Eighteen samples for X-ray diffraction and organic matter optical analyses were collected from the shaly and silty intervals contained in the succession cropping out along the Dniestr River. As the sedimentary succession is mainly composed of calcareous lithologies with interbedded shales, samples suitable for thermochronology derive exclusively from Silurian bentonite layers and from finegrained Devonian sandstones. Silurian apatites are all euhedral crystals, as expected from a volcanogenic source, whereas those contained in Devonian strata are small $(<60 \mu \mathrm{m})$ and rounded, therefore not suitable for apatite (U-Th/He) dating. Sampling locations and lithologies are reported in Fig. 2 and Table 1.

\section{Indicators of maximum burial}

\section{Clay mineralogy}

Mineralogical assemblages of whole rock and $<2 \mu \mathrm{m}$ fraction of sediments were determined by X-ray diffraction performed using a Scintag X1 XRD system (CuK $\alpha$ radiation, solid-state detector, spinning sample) at $40 \mathrm{kV}$ and $45 \mathrm{~mA}$. Randomly oriented whole-rock powders were run in the $2-70^{\circ} 2 \Theta$ interval with a step size of $0.05^{\circ} 2 \Theta$ and a counting time of $3 \mathrm{~s}$ per step. Oriented air-dried (AD) samples were scanned from 1 to $48^{\circ} 2 \Theta$ with a step size of $0.05^{\circ} 2 \Theta$ and a count time of $4 \mathrm{~s}$ per step. The presence of expandable clay minerals was determined for samples treated with ethylene glycol at room temperature for 


\section{A. Schito et al.}

24 h. Ethylene glycol (EG)-solvated samples were scanned at the same conditions as air-dried aggregates with a scanning interval of $1-30^{\circ} 2 \Theta$. The $<2 \mu \mathrm{m}$ grainsize fraction was separated by centrifuging, and oriented slides were prepared by the pipette-on-slide method (Moore \& Reynolds, 1997), keeping the specimen thickness as constant as possible, with at least $3 \mathrm{mg}$ of clay per $\mathrm{cm}^{2}$ of glass slide.

Expandability measurements for both I-S and chloritesmectite (C-S) mixed-layer minerals were determined according to Moore \& Reynolds (1997) using the ${ }^{\circ} \Delta 2 \Theta$ method after decomposing the composite peaks between $9-10^{\circ} 2 \Theta$ and $16-17^{\circ} 2 \Theta$ for I-S and between $10-12.3^{\circ} 2 \Theta$ and $25-26^{\circ} 2 \Theta$ for C-S using Pearson VII functions.

\section{Organic matter optical analysis}

Vitrinite derives from thermal maturation of woody tissues of vascular plants and its reflectance is in general the most accepted thermal maturity indicator. In order to carry out the analyses, the samples were first crushed in an agate mortar, mounted in epoxy resin and finally polished according to standard procedures described in Bustin et al. (1990). Reflectance analyses were then performed using a Zeiss Axioskop $\times 40$ microscope, equipped with a conventional microphotometric system (MSP200 by J\&M), under oil immersion $(n=1.518)$ in reflected monochromatic non-polarised light $(\lambda=546 \mathrm{~nm})$.

Ordovician and Silurian successions of this study are in general devoid of organic matter of terrestrial origin. Nevertheless, for the lowermost Palaeozoic samples the increase in reflectance of marine organoclasts (i.e. graptolites, chitinozoas, conodonts) was calibrated against thermal maturity according to Bertrand and Malo's correlation (2012). Organic matter particles were collected from sandstones, siltstones and clays. Mean random reflectance on organoclasts $\left(\mathrm{R}_{\mathrm{o}} \%\right.$ org $)$ and vitrinite reflectance $\left(\mathrm{R}_{\mathrm{o}} \%\right)$ were measured on Silurian and Devonian whole-rock samples, respectively. The mean organoclast reflectance $\left(\mathrm{R}_{\mathrm{o}} \% \mathrm{eq}\right)$ values for Silurian samples were converted according to Bertrand and Malo's equation (2012) since only graptolite fragments were measured.

\section{Fission-track analysis}

Sample preparation for apatite fission-track analysis was performed according to Donelick et al. (2005). Apatite grains were separated after careful crushing using heavy liquids and magnetic separation techniques. Mounts of apatites in epoxy were ground and polished to expose planar surfaces within the grains and then etched with 5.5 M $\mathrm{HNO}_{3}$ at $21{ }^{\circ} \mathrm{C}$ for $20 \mathrm{~s}$ to reveal spontaneous fission tracks. Samples then were irradiated with thermal neutrons in the reactor at the Radiation Center of Oregon State University with a nominal neutron fluence of $9 \times 10^{15} n \mathrm{~cm}^{-2}$. The CN-5 dosimeter was used to measure neutron fluence. After irradiation, induced fission tracks in the low-U muscovite that covered apatite grain mounts and glass dosimeter were revealed by etching in $40 \% \mathrm{HF}$ at $20^{\circ} \mathrm{C}$ for $40 \mathrm{~min}$. AFT dates were calculated using the external-detector and the zeta-calibration methods (Hurford \& Green, 1983) with IUGS age standards (Durango, Fish Canyon and Mount Dromedary apatites; Hurford, 1990) and a value of 0.5 for the $4 \pi / 2 \pi$ geometry correction factor. The analyses were subjected to the $\chi^{2}$ test (Galbraith, 1981) to detect whether the data sets contained any extra-Poissonian error. A $\chi^{2}$ probability of $<5 \%$ denotes a significant spread of single grain dates. Dpar (i.e. the diameter of etch figures parallel to the crystallographic c-axis; Ketcham et al., 1999) of single crystals was measured and used as a kinetic parameter. Wherever possible, track densities were measured on more than 20 grains per sample, and as many horizontal confined track lengths as possible were measured, to better constrain the $\mathrm{t}-\mathrm{T}$ paths of single sample (Gleadow et al., 1986; Braun et al., 2006).

\section{Apatite (U-Th)/He dating}

Apatite (U-Th)/He dating (AHe) was carried out at the University of Arizona $\mathrm{He}$ dating laboratory. Apatite grains which satisfied quality requirements (e.g. no inclusions, $>60 \mu \mathrm{m}$ in minimum dimension, etc.; see Ehlers $\&$ Farley, 2003) were extracted from heavy mineral separates and up to five crystals measured for alpha-ejection correction following methods described in Reiners et al. (2007). Single crystals were loaded into $0.8 \mathrm{~mm} \mathrm{Nb}$ tubes, and degassed under vacuum by heating with a Nd-YAG laser. The concentration of $4 \mathrm{He}$ was determined by $3 \mathrm{He}$ isotope dilution and measurement of the $4 \mathrm{He} / 3 \mathrm{He}$ ratio through a quadrupole mass spectrometer. U, Th and Sm concentrations were obtained by isotope dilution using an inductively coupled plasma mass spectrometer.

\section{Thermal modelling}

The HeFTy 1.8.1 software (Ketcham, 2005), which generates T-t paths using a Monte Carlo algorithm, was used to perform inverse thermal modelling on four samples (M2, M6, C3, C6) to integrate the AHe and AFT data and test valid thermal history scenarios. AFT ages and lengths (where present) and AHe data were used for modelling. Only one AHe replicate was used for each sample (i.e. that bearing the minimum age; see section "Results and interpretation" below). Modelling was based on the fission-track annealing model of Ketcham et al. (2007) and on the model for He diffusion kinetics in apatite of Flowers et al. (2009). A homogeneous distribution of $U$ and $\mathrm{Th}$ in apatite was assumed.

\section{Burial modelling}

Palaeothermal and geochronological data were used as constraints to perform numerical models of the burial history of the area. Three pseudo-wells were calibrated by 
Table 2. Analytical data from thermal maturity analysis, indicating: sample age, organoclast and/or vitrinite reflectance and related standard deviation, illite content in mixed layers illite-smectite and semiquantitative analysis of whole rock composition and $<2 \mu \mathrm{m}$ grain size fraction

\begin{tabular}{|c|c|c|c|c|c|}
\hline \multirow[b]{2}{*}{ Sample } & \multirow[b]{2}{*}{ Age } & \multirow[b]{2}{*}{ Ro\% \pm SD (n. meas.) } & \multirow[b]{2}{*}{$\% \mathrm{I}$ in $\mathrm{I}-\mathrm{S}$} & \multicolumn{2}{|l|}{ XRD analisys } \\
\hline & & & & $<2 \mu \mathrm{m}$ & Whole rock \\
\hline Po24 & Lower Devonian & - & 86 & $\mathrm{I}_{81} \mathrm{I}_{-} \mathrm{S}_{4} \mathrm{Ch}_{15}$ & $\mathrm{Qtz}_{9} \mathrm{Plg}_{5} \mathrm{Ph}_{85} \mathrm{Sid}_{1}$ \\
\hline Po15 & Lower Devonian & - & 86 & $\mathrm{I}_{54} \mathrm{I}-\mathrm{S}_{20} \mathrm{~K}_{4} \mathrm{Ch}_{22}$ & $\mathrm{Qtz}_{11} \mathrm{Cal}_{1} \mathrm{Plg}_{5} \mathrm{Ph}_{82} \mathrm{Sid}_{1}$ \\
\hline Po16 & Lower Devonian & - & 85 & $\mathrm{I}_{62} \mathrm{I}-\mathrm{S}_{14} \mathrm{~K}_{7} \mathrm{Ch}_{17}$ & $\mathrm{Qtz}_{9} \mathrm{Cal}_{5} \mathrm{Plg}_{5} \mathrm{Ph}_{80} \mathrm{Ank}_{1}$ \\
\hline Po13 & Lower Devonian & - & 86 & $\mathrm{I}_{59} \mathrm{I}-\mathrm{S}_{7} \mathrm{~K}_{5} \mathrm{Ch}_{29}$ & $\mathrm{Qtz}_{11} \mathrm{Plg}_{8} \mathrm{Ph}_{80} \mathrm{Sid}_{1}$ \\
\hline Po12 & Lower Devonian & - & 86 & $\mathrm{I}_{56} \mathrm{I}_{-} \mathrm{S}_{10} \mathrm{~K}_{5} \mathrm{Ch}_{29}$ & $\mathrm{Qtz}_{13} \mathrm{Plg}_{8} \mathrm{Ph}_{79}$ \\
\hline Po23 & Lower Devonian & $0.87 \pm 0.08(5)$ & 89 & $\mathrm{I}_{56} \mathrm{I}-\mathrm{S}_{15} \mathrm{~K}_{12} \mathrm{Ch}_{17}$ & $\mathrm{Qtz}_{10} \mathrm{Cal}_{2} \mathrm{Plg}_{5} \mathrm{Ph}_{82} \mathrm{Sid}_{1}$ \\
\hline Po20 & Upper Pridoli & - & 85 & $\mathrm{I}_{73} \mathrm{I}-\mathrm{S}_{5} \mathrm{~K}_{6} \mathrm{Ch}_{16}$ & $\mathrm{Qtz}_{6} \mathrm{Cal}_{23} \mathrm{Kfs}_{1} \mathrm{Plg}_{4} \mathrm{Ph}_{57} \mathrm{Dol}_{5} \mathrm{Ank}_{4}$ \\
\hline Po17 & Pridoli & - & 90 & $\mathrm{I}_{73} \mathrm{I}-\mathrm{S}_{8} \mathrm{~K}_{4} \mathrm{Ch}_{14}$ & $\mathrm{Qtz}_{6} \mathrm{Kfs}_{1} \mathrm{Plg}_{3} \mathrm{Ph}_{75} \mathrm{Dol}_{15}$ \\
\hline Po10 & Ludlowian & - & 90 & $\mathrm{I}_{46} \mathrm{I}-\mathrm{S}_{4} \mathrm{~K}_{25} \mathrm{Ch}_{25}$ & $\mathrm{Qtz}_{18} \mathrm{Cal}_{23} \mathrm{Kfs}_{2} \mathrm{Plg}_{8} \mathrm{Ph}_{43} \mathrm{Sid}_{1} \mathrm{Dol}_{1} \mathrm{Ank}_{4}$ \\
\hline Po11 & Ludlowian & $0.65 \pm 0.07(4)$ & 90 & $\mathrm{I}_{65} \mathrm{I}-\mathrm{S}_{7} \mathrm{~K}_{8} \mathrm{Ch}_{20}$ & $\mathrm{Qtz}_{10} \mathrm{Cal}_{1} \mathrm{Kfs}_{2} \mathrm{Plg}_{8} \mathrm{Ph}_{69} \mathrm{Sid}_{1} \mathrm{Dol}_{3} \mathrm{Ank}_{6}$ \\
\hline Po19 & Ludlowian & - & 89 & $\mathrm{I}_{65} \mathrm{I}-\mathrm{S}_{16} \mathrm{Ch}_{19}$ & $\mathrm{Qtz}_{10} \mathrm{Cal}_{15} \mathrm{Kfs}_{2} \mathrm{Plg}_{5} \mathrm{Ph}_{56} \mathrm{Sid}_{1} \mathrm{Dol}_{11}$ \\
\hline Po18 & Ludlowian & - & 89 & $\mathrm{I}_{62} \mathrm{I}-\mathrm{S}_{17} \mathrm{C}-\mathrm{S}_{7} \mathrm{~K}_{4} \mathrm{Ch}_{10}$ & $\mathrm{Qtz}_{9} \mathrm{Kfs}_{1} \mathrm{Plg}_{6} \mathrm{Ph}_{74} \mathrm{Sid}_{1} \mathrm{Dol}_{9}$ \\
\hline Po4 & Wenlockian & - & 85 & $\mathrm{I}_{55} \mathrm{I}-\mathrm{S}_{31} \mathrm{C}-\mathrm{S}_{3} \mathrm{~K}_{4} \mathrm{Ch}_{7}$ & $\mathrm{Qtz}_{6} \mathrm{Cal}_{48} \mathrm{Plg}_{2} \mathrm{Ph}_{42} \mathrm{Dol}_{2}$ \\
\hline Po3 & Llandoverian & $0.75 \pm 0.12(5)$ & 88 & $\mathrm{I}_{52} \mathrm{I}-\mathrm{S}_{25} \mathrm{~K}_{12} \mathrm{Ch}_{11}$ & $\mathrm{Qtz}_{27} \mathrm{Kfs}_{3} \mathrm{Plg}_{7} \mathrm{Ph}_{63}$ \\
\hline Po2 & Llandoverian & $0.77 \pm 0.08(3)$ & 85 & $\mathrm{I}_{52} \mathrm{I}-\mathrm{S}_{30} \mathrm{C}-\mathrm{S}_{10} \mathrm{~K}_{4} \mathrm{Ch}_{4}$ & $\mathrm{Qtz}_{13} \mathrm{Kfs}_{1} \mathrm{Plg}_{7} \mathrm{Ph}_{79}$ \\
\hline Po1 & Llandoverian & - & 85 & $\mathrm{I}_{42} \mathrm{I}-\mathrm{S}_{25} \mathrm{C}-\mathrm{S}_{13} \mathrm{~K}_{7} \mathrm{Ch}_{13}$ & $\mathrm{Qtz}_{19} \mathrm{Kfs}_{1} \mathrm{Plg}_{9} \mathrm{Ph}_{71}$ \\
\hline Po7 & Ordovician & - & 84 & $\mathrm{I}_{26} \mathrm{I}-\mathrm{S}_{17} \mathrm{Ch}_{57}$ & $\mathrm{Qtz}_{16} \mathrm{Kfs}_{1} \mathrm{Plg}_{19} \mathrm{Ph}_{64}$ \\
\hline Po8 & Ordovician & - & 82 & $\mathrm{I}_{34} \mathrm{I}_{-} \mathrm{S}_{35} \mathrm{~K}_{14} \mathrm{Ch}_{17}$ & $\mathrm{Qtz}_{13} \mathrm{Kfs}_{2} \mathrm{Plg}_{12} \mathrm{Ph}_{73}$ \\
\hline
\end{tabular}

Acronyms: $\mathrm{I}=$ illite; $\mathrm{I}-\mathrm{S}=$ mixed layers illite-smectite; $\mathrm{K}=$ kaolinite; $\mathrm{Ch}=$ chlorite; $\mathrm{C}-\mathrm{S}=$ mixed layers chlorite-smectite; $\mathrm{Qtz}=$ quartz; $\mathrm{Cal}=\mathrm{cal}-$ cite $\mathrm{Ph}=$ phyllosilicates; $\mathrm{Plg}=\mathrm{Na}$-plagioclase $; \mathrm{Kfs}=\mathrm{K}$-feldspar; $\mathrm{Dol}=$ dolomite; $\mathrm{Sid}=$ siderite; Ank = ankerite.

organic and inorganic thermal maturity data derived from the Lower Silurian successions cropping out close to the EEC (psedowell 3) and from the Upper Silurian (psedowell 2), as well as from Devonian successions (pseudowell 1) cropping out to the west. Pseudo-wells were built by considering the thickness variations due to the westward deepening of the basin and using thicknesses measured in the field or collected from previous works (Oncken, 1982; Nöth et al., 2001). Exhumation stages were constrained by apatite fission track data and U-Th/He dating.

Simplified reconstructions of the burial and thermal history for the Ordovician-Devonian successions have been performed using the software package Basin $\operatorname{Mod}^{\circledR}$ 1-D (1996). The main assumptions for modelling are the following: (i) rock decompaction factors apply only to clastic deposits (Sclater \& Christie,1980); (ii) seawater depth variations in time are assumed as not relevant, because thermal evolution is mainly affected by sediment thickness rather than by water depth (Butler, 1992); (iii) thermal modelling is performed using LLNL Easy \% $\mathrm{R}_{\mathrm{o}}$ method based on Burnham \& Sweeney (1989) and Sweeney \& Burnham (1990) and (iv) heat flow values vary through time, based on available constraints (Botor et al., 2002; Poprawa et al., 2005 and Carozzo et al., 2012), from $50 \mathrm{~mW} \mathrm{~m}^{-2}$ in the Paleozoic and Mesozoic with a peak of $65 \mathrm{mw} / \mathrm{m}^{2}$ during the Carboniferous, to $30 \mathrm{~mW} \mathrm{~m}^{-2}$ during the Cenozoic.

Rock properties including initial porosity, compaction data, density, conductivity and heat capacity were chosen from the software libraries among those available for pure or mixed lithologies. Illite content in mixed layers I-S was converted into vitrinite reflectance equivalent values on the basis of the correlation between these two palethermal indicators from Aldega et al. (2007) and Merriman \& Frey (1999).

\section{RESULTS AND INTERPRETATION Clay mineralogy}

Randomly oriented whole-rock powders from the collected Devonian samples show a mineralogical assemblage composed of phyllosilicates (in the range of 79-85\%), quartz $(9-13 \%)$, plagioclase $(5-8 \%)$ and subordinate amounts of calcite, siderite and ankerite (1-6\%; Table 2). Minor contents of $\mathrm{K}$-feldspars (1\%) occasionally occur. The $<2 \mu \mathrm{m}$ grain size fraction is constituted by illite (56$81 \%$ ), mixed layers illite-smectite (4-20\%), chlorite (15$29 \%$ ) and kaolinite (0-12\%). Mixed layers illite-smectite are long-range ordered structures with an illite content ranging between $85-89 \%$ (Fig. 4).

In the Silurian succession, Wenlockian to Pridoli rocks are characterised by phyllosilicates (43-75\%), quartz (6-18\%), plagioclase (2-8\%), K-feldspar (1$2 \%$ ) and higher amounts of carbonate minerals with respect to the Devonian units. Calcite ranges between 1 and $48 \%$, dolomite between 1 and $15 \%$, while ankerite never exceeds $6 \%$. Siderite is a minor component of the carbonate fraction, with contents of about $1 \%$. On the other hand, the Llandoverian portion of the succession does not show carbonate minerals and is 


\section{A. Schito et al.}

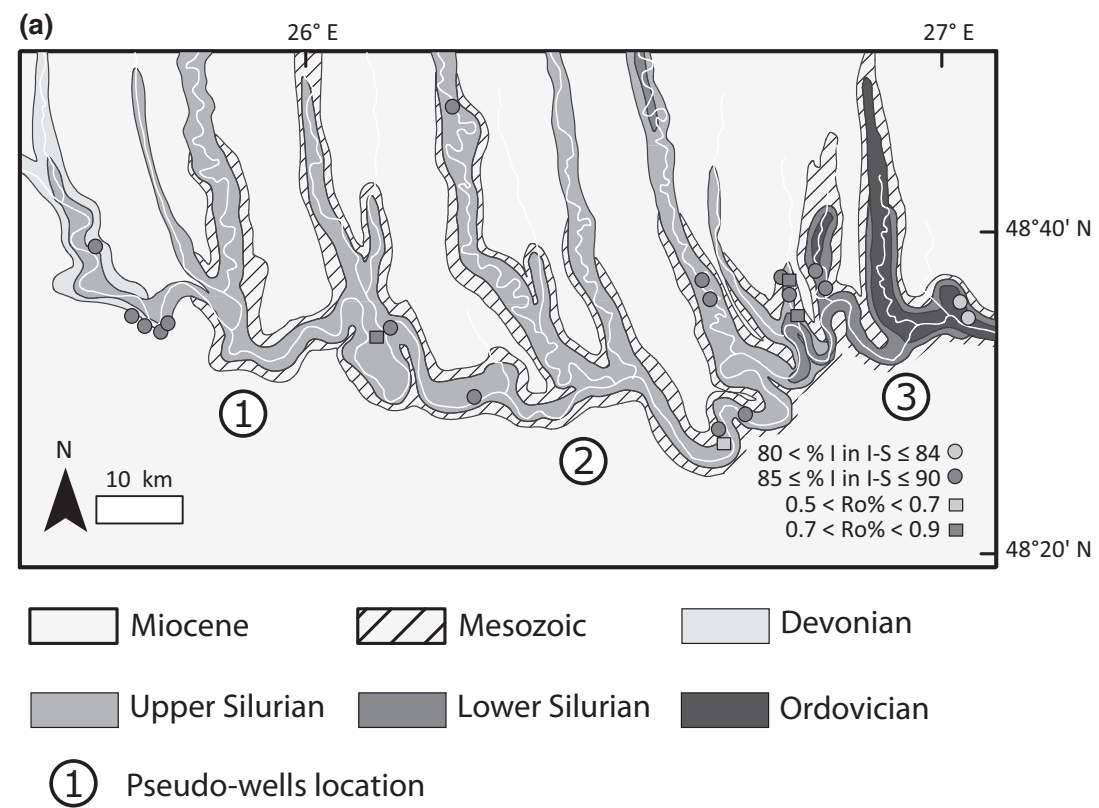

(b)

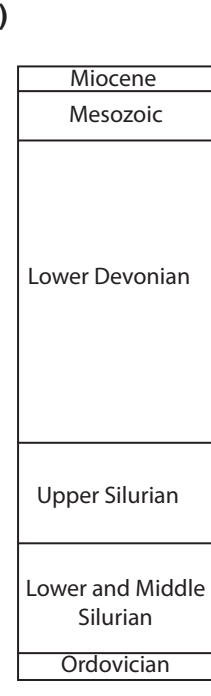

(1)

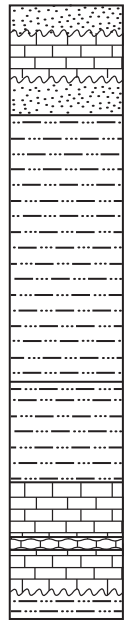

(2)

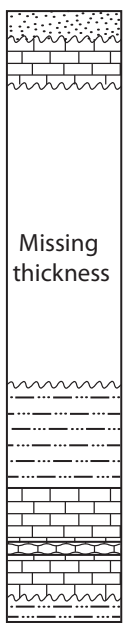

(3)

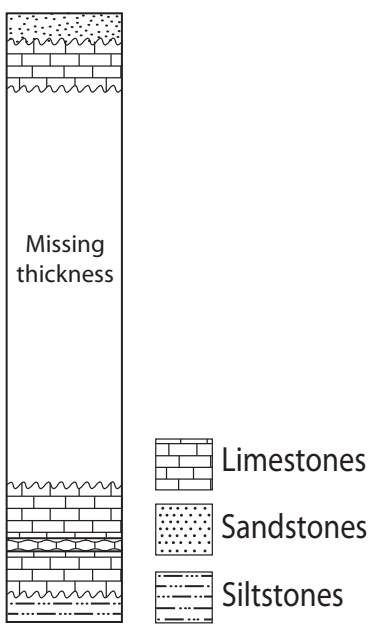

Fig. 4. (a) Geological map of the Dniestr River area, showing values of paleothermal indicators. (b) Pseudo-well stratigraphies used as input for 1D burial models.

mainly constituted by phyllosilicates $(63-79 \%)$ and quartz (13-27\%), with subordinate amounts of plagioclase $(7-9 \%)$ and $\mathrm{K}$-feldspar (1-3\%).

$\mathrm{X}$-ray diffraction analysis of the $<2 \mu \mathrm{m}$ grain-size fraction for the Silurian rocks displays illite $(42-73 \%)$, long-range ordered mixed layer illite-smectite (4-31\%), kaolinite (0-25\%) and chlorite (4-25\%) (Table 2). Furthermore, in a few samples (PO1, PO2, PO4, PO18), mixed layers chlorite-smectite with a chlorite content of $70-80 \%$ were detected. Mixed layered clay minerals are low expandable illite-smectite with an illite content ranging between $85 \%$ and $90 \%$ (Fig. 4 and Table 2).

Ordovician rocks are composed of phyllosilicates (64 $73 \%)$, plagioclase (12-19\%), quartz (13-16\%) and low amounts of K-feldspar (1-2\%; Table 2). Among minerals of the $<2 \mu \mathrm{m}$ grain size fraction, chlorite $(17-57 \%)$, illite
(26-34\%), kaolinite (0-14\%) and mixed layer illite-smectite (17-35\%) were identified (Table 2). Mixed layered clay minerals are long-range ordered Illite-smectite with an illite content of $82-84 \%$ (Fig. 4).

\section{Organic matter reflectance data}

The collected samples are very poor in organic matter content (Table 2). Reflectance was measured on vitrinitelike fragments and graptolites in the Silurian-Devonian stratigraphic interval. The results of the conversion of organoclasts reflectance data into vitrinite reflectance equivalent data are reported in Table 2 and Fig. 4.

In the Lochkovian interval, a $\mathrm{R}_{\mathrm{o}} \%$ eq value of $0.87 \%$ was measured (sample PO23). A value of $0.65 \%$ has been obtained on sample PO11 from marly mudstones of Ludlowian age. In pelites of Landoverian age, two samples 


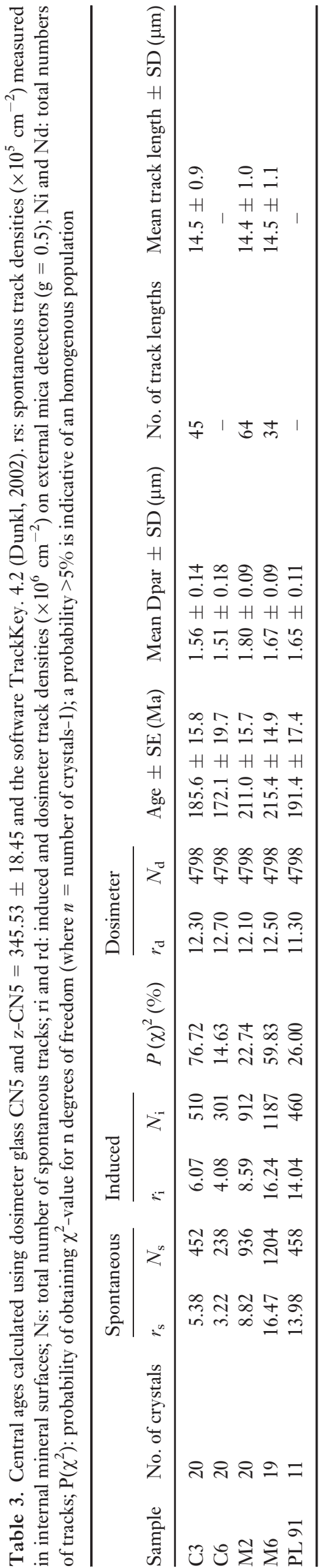

(PO2, PO3) provided reliable $\mathrm{R}_{\mathrm{o}} \%$ eq with a mean value of about $0.76 \%$.

\section{Thermochronology}

Up to 20 grains per sample have been analysed for AFT. The results (Table 3 and Fig. 5) indicate a low spread of single grain ages (between 0 and 21\%; Fig. 5) and the chi-square test displays that only one age population is present in each sample. Track lengths measurement of $t$ was only possible on Silurian samples, and in samples C3 and M2 the number of lengths was high enough to be representative of the track length distribution (Braun $e t$ al., 2006; Table 3). As a whole, the AFT dataset is rather consistent and indicates: (i) heating at temperatures exceeding the total reset temperature (as all the single grain ages are younger than the stratigraphic age), and (ii) a Late Triassic-Early Jurassic cooling phase. In three samples (M2, C6, PL91), a few grains younger than $120 \mathrm{Ma}$ are present, suggesting that a very faint degree of reset might have affected these samples since the Cretaceous.

AHe ages show a large age dispersion among the five replicates of each sample (Table 4). In particular, samples M2, M6 and C3 show up to 400 Ma span among replicate dates. Age spread is limited for sample C6, where single grain ages range between 162 and $241 \mathrm{Ma}$. Despite the high data dispersion, Fig. 6 and Tables 3 and 4 show that the minimum ages detected for each sample are consistent (160-176 Ma) and match the AFT central ages (these being, as expected, slightly older: 172$215 \mathrm{Ma}$ ). Based on correlations between single grain ages and grain size (Rs), $\mathrm{U}$ and $\mathrm{Th}$ contents (eU: effective Uranium $=[\mathrm{U}]+0.235 \times[\mathrm{Th}]$; Shuster et al., 2006, [U], [Th]) and $\mathrm{Th} / \mathrm{U}$ ratio, several hypotheses (listed below) for the possible sources of high age dispersion were tested; in several cases negative correlations between age and Rs, eU, [Th] and Th/U occur (Fig. 7).

- A He excess from U, Th rich inclusions would explain younger dates occurring in $\mathrm{U}$ and $\mathrm{Th}$ richer grains. However, (i) inclusions are generally small (their dimensions is very close to $1 / 10$ of the dimensions of the apatite grains), thus requiring an $\mathrm{eU}$ higher than ca. $2000 \mathrm{ppm}$ to justify such older dates; (ii) the random distribution expected for the size and composition of the inclusions would not fit with the correlations observed between $\mathrm{AHe}$ dates and grain radius, $\mathrm{eU},[\mathrm{Th}]$ and $\mathrm{Th} / \mathrm{U}$; (iii) no clear relation between the presence of big inclusions and the occurrence of old dates, nor, on the contrary, between the absence of inclusions and young dates are observed; and (iv) Volcanic apatites not exposed to subsequent metamorphism are not known to possibly contain monazite (i.e. U-Th very rich inclusions). Therefore, a major role of inclusions in determining high data dispersion is not convincing.

- Age dispersion caused by slow cooling and/or partial reset is also not convincing since, in that case, a direct, 

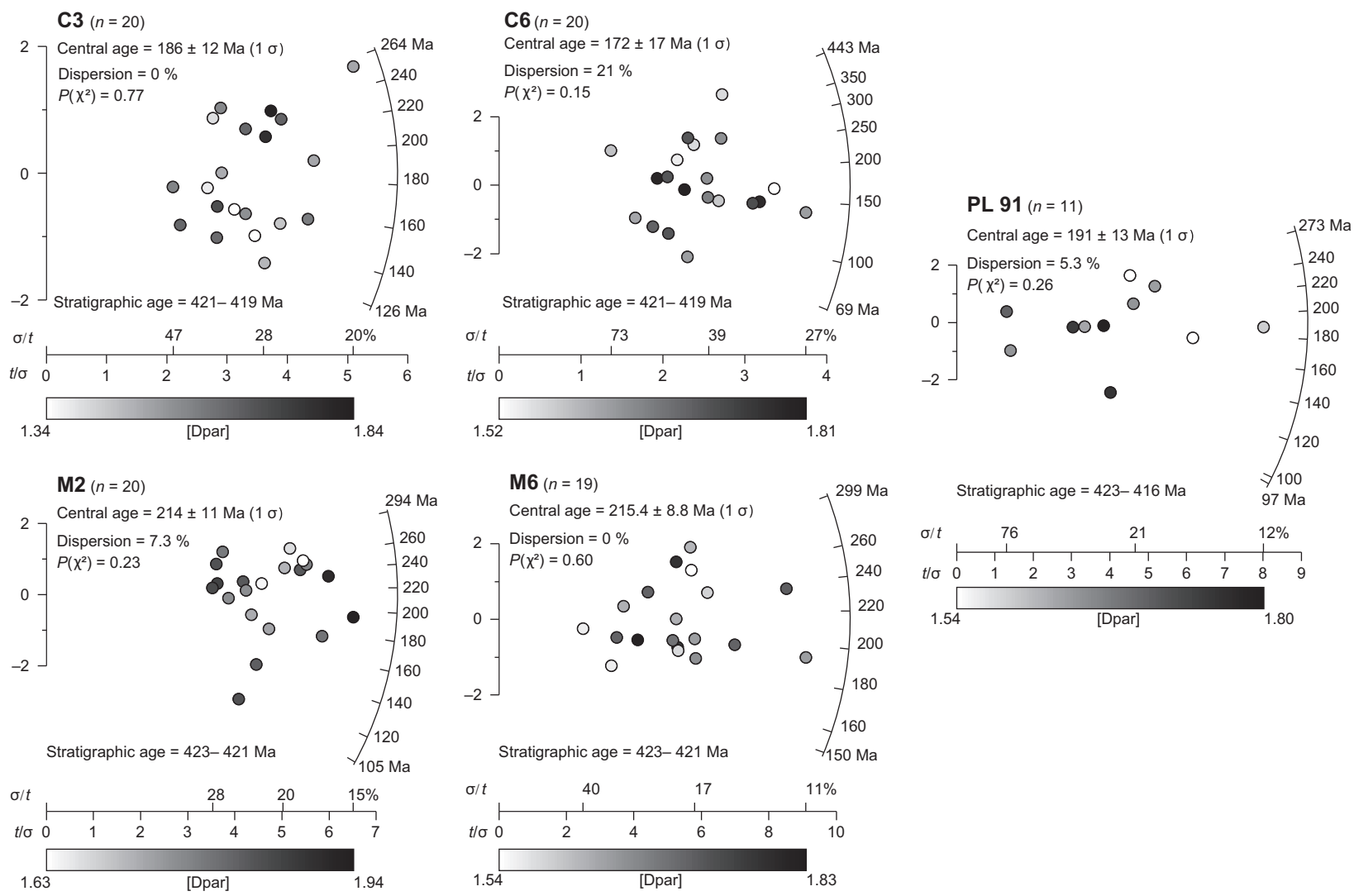

Fig. 5. Radial plots of apatite fission-track data. $n$ : number of analysed grains; $\mathrm{P}\left(\chi^{2}\right)$ : probability of obtaining $\chi^{2}$-value for $v$ degrees of freedom (where $v=$ number of crystals-1); a probability $>5 \%$ is indicative of an homogenous population; Dpar: length of the etch pit figure.

rather than an inverse correlation between $\mathrm{AHe}$ dates and Rs would be expected.

- A thermal modelling of the five replicates was attempted using the Flowers et al. (2009)'s Radiation Damage Apatite Annealing Model for He diffusion to test a possible effect of radiation damages, but no acceptable results were obtained.

- Furthermore, there is no clear connection between abrasion or breaks in the crystals and dates.

- Finally, the correlations found among dates and Rs, $\mathrm{eU}, \mathrm{Th}, \mathrm{Th} / \mathrm{U}$ suggest that, at least in three samples, a major and systematic effect caused age dispersion, therefore a combination of several causes must also be ruled out.

- He implantation in the crystals from external U-Th rich sources is considered the most reasonable hypothesis for He dispersion since it would explain the observed correlations: bigger and U-Th rich grains bear younger ages. In fact, these grains are less sensitive to the age increase caused by excess He from external sources. This is also supported by the good match among the minimum ages of each crystal and between minimum age and AFT central age.

Therefore, we consider only the youngest ages, obtained from the biggest and U-Th richest grains, to be the most correct ones and maintain them for the following discussion.
AFT and AHe ages have been then modelled using the HeFTy software (Fig. 8; Ketcham, 2005). Thermal models were performed using AFT dates and lengths (where present) and the youngest $\mathrm{He}$ date for each sample. The T-t constraints used were: (i) $0-20{ }^{\circ} \mathrm{C}$ at the depositional age; (ii) $100-210{ }^{\circ} \mathrm{C}$ in the Paleozoic burial stage; (iii) 0 $50{ }^{\circ} \mathrm{C}$ during the Cretaceous, when Silurian rocks were at surface (Fig. 7); (iv) $0-100{ }^{\circ} \mathrm{C}$ in the post-Albian to force the model testing the heating event proposed by Środon et al. (2013).

Thermal modelling results (Fig. 8) indicate that the present thermochronometric dataset can be explained by a major cooling event in the Late Triassic-Early Jurassic, following a period of heating and possible retention to temperatures higher than ca. $120{ }^{\circ} \mathrm{C}$ (AFT total reset temperature). As the results of thermal modelling are fully reliable only for the temperature intervals corresponding to the partial retention zones of the applied thermochronometers, i.e. $40-120{ }^{\circ} \mathrm{C}$, our thermochronological modelling is not able to detail the thermal path for temperatures higher than $120{ }^{\circ} \mathrm{C}$ and lower than $40{ }^{\circ} \mathrm{C}$. However, some sedimentation is expected to have taken place after the Early Jurassic (as described by Środoń et al., 2013; Fig. 3). This can be observed in Fig. 8, where good fitting thermal histories are found also with heating up to $50-70{ }^{\circ} \mathrm{C}$ in post-Albian times. However, the total amount of sediments was not sufficient to reset the $\mathrm{AHe}$ system. Therefore, assuming a surface 


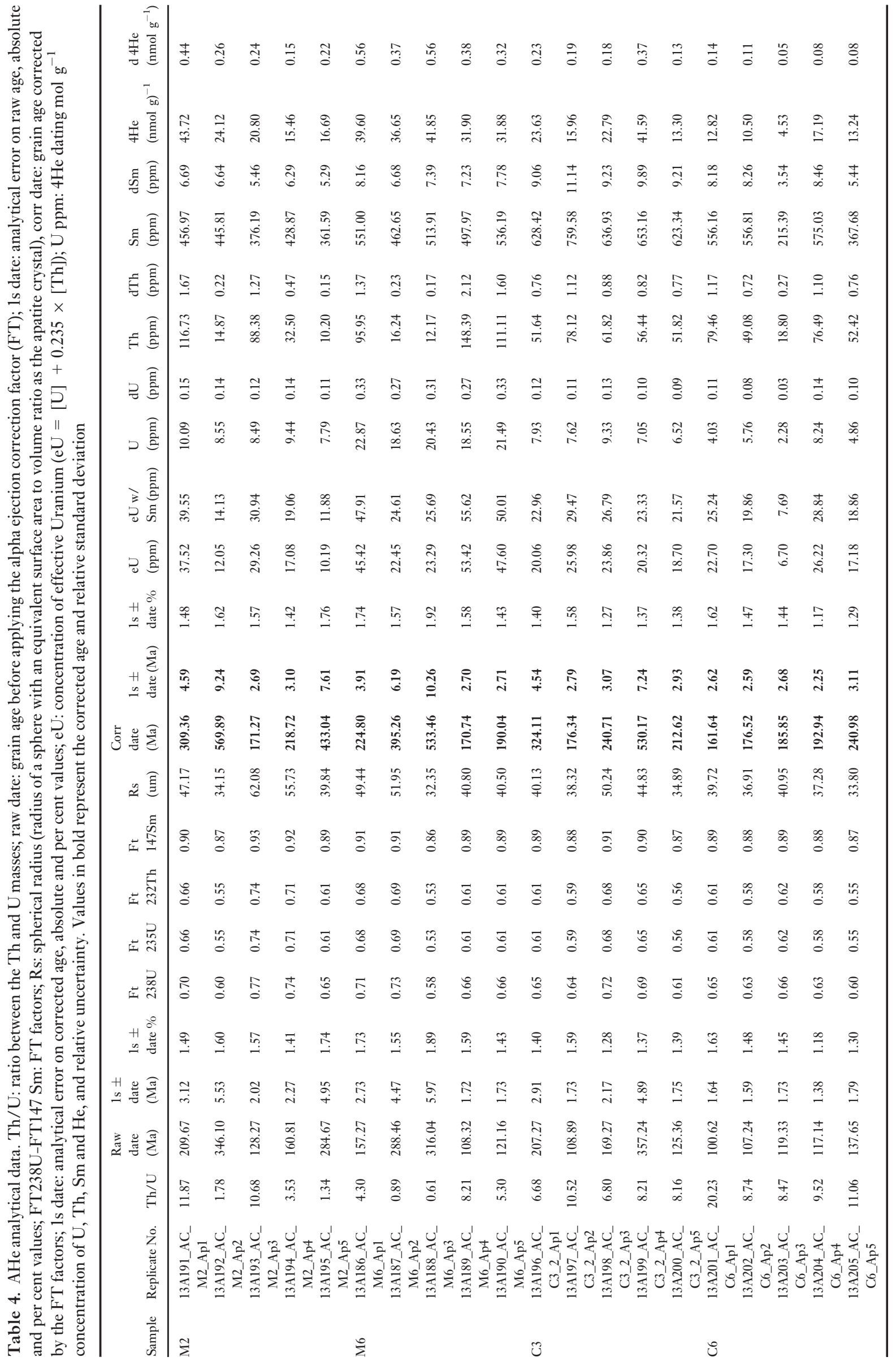




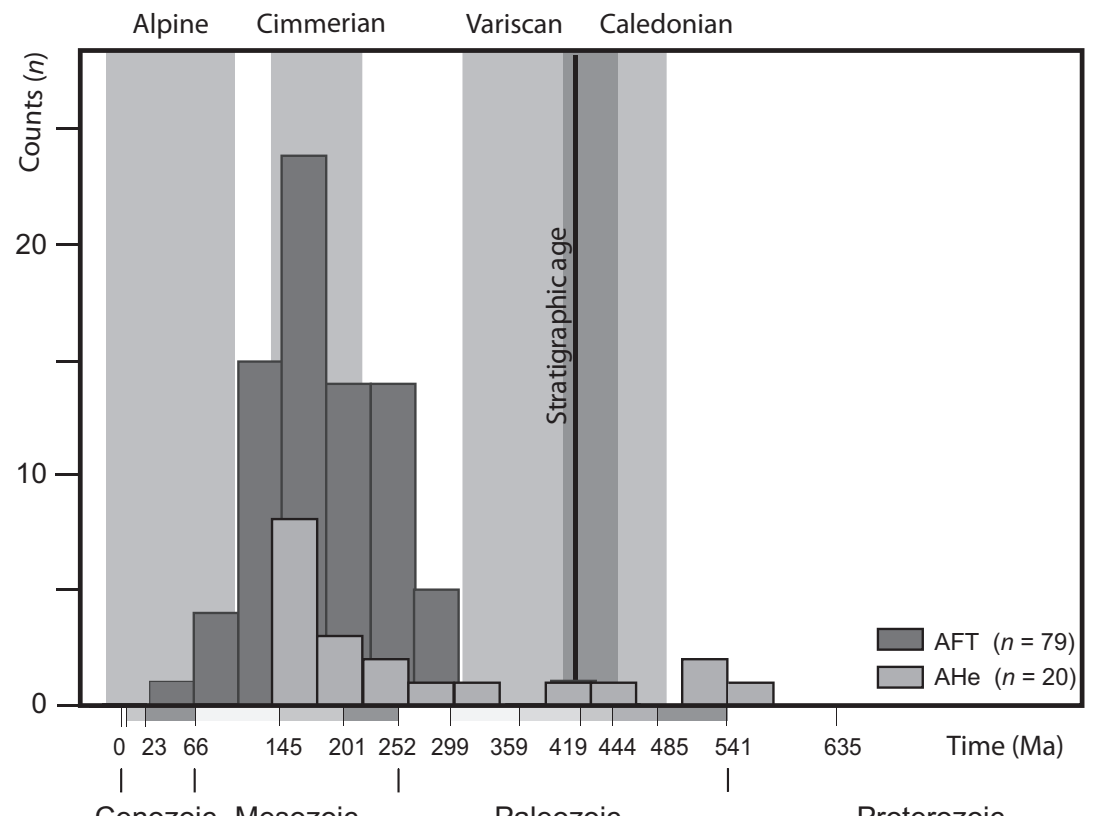

$\begin{array}{lll}\text { Cenozoic Mesozoic } & \text { Paleozoic } & \text { Proterozoic }\end{array}$
Fig. 6. Histograms of apatite fissiontrack (dark grey bars) and $\mathrm{U}-\mathrm{Th} / \mathrm{He}$ (light grey bars) ages, and time range of the main orogenic events.
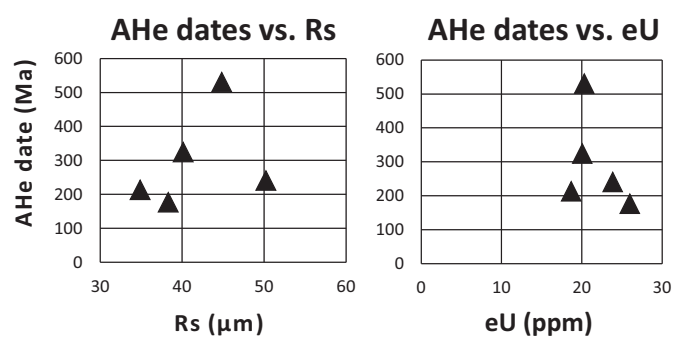

AHe dates vs. [U]

AHe dates vs. [Th]

AHe dates vs. Th/U

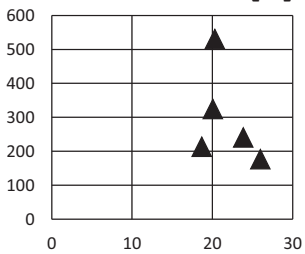

[U] (ppm)
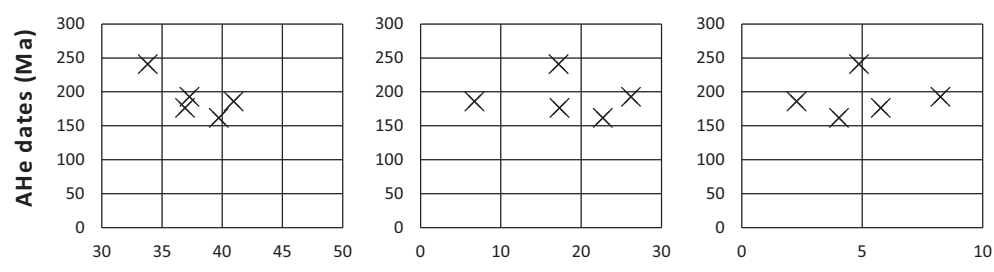

[U] (ppm)
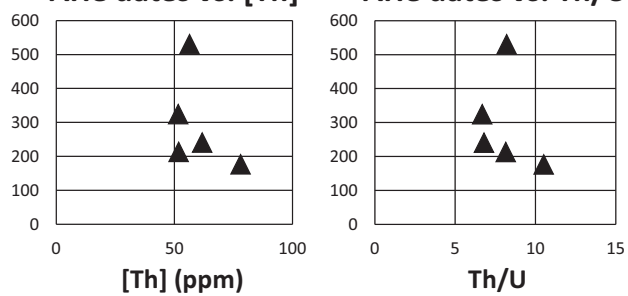

[Th] (ppm)

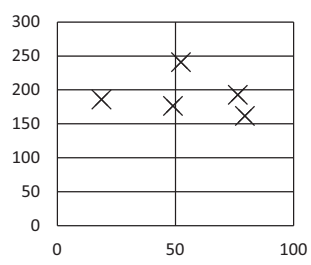

[Th] (ppm)
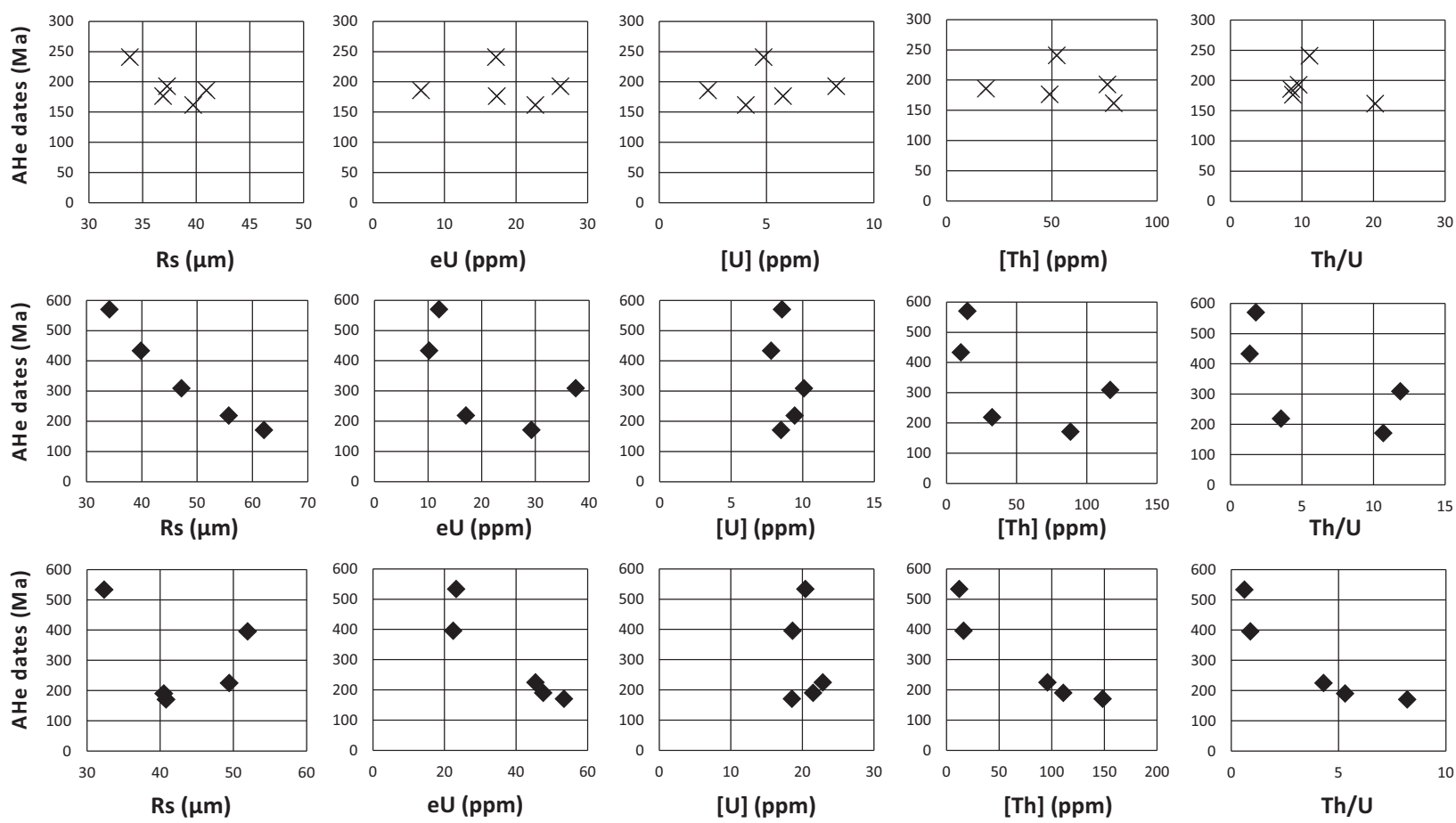

Fig. 7. Correlation diagrams of AHe ages of single sample and grain radius (Rs), effective Uranium concentration $(\mathrm{eU}=[\mathrm{U}]$ $+0.235 \times[\mathrm{Th}] ;$ Shuster et al., 2006); $\mathrm{U}$ and Th concentrations; Th/U ratio. 

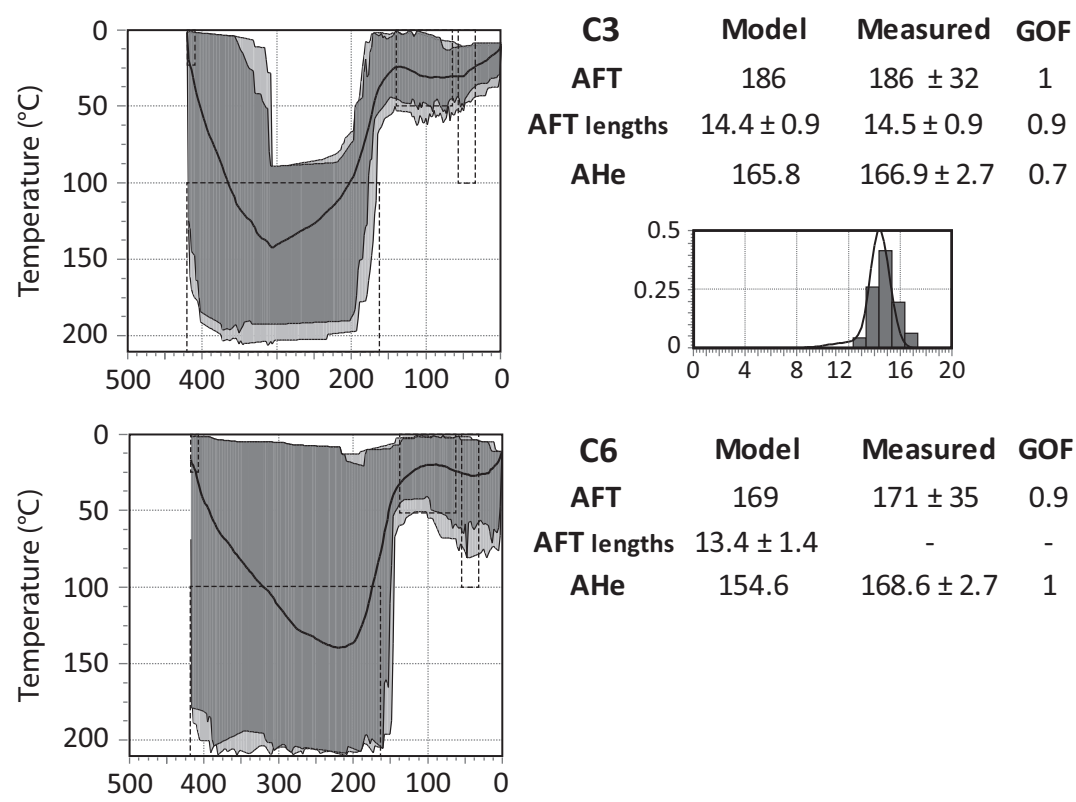

$\begin{array}{cccc}\text { C6 } & \text { Model } & \text { Measured } & \text { GOF } \\ \text { AFT } & 169 & 171 \pm 35 & 0.9 \\ \text { AFT lengths } & 13.4 \pm 1.4 & - & - \\ \text { AHe } & 154.6 & 168.6 \pm 2.7 & 1\end{array}$
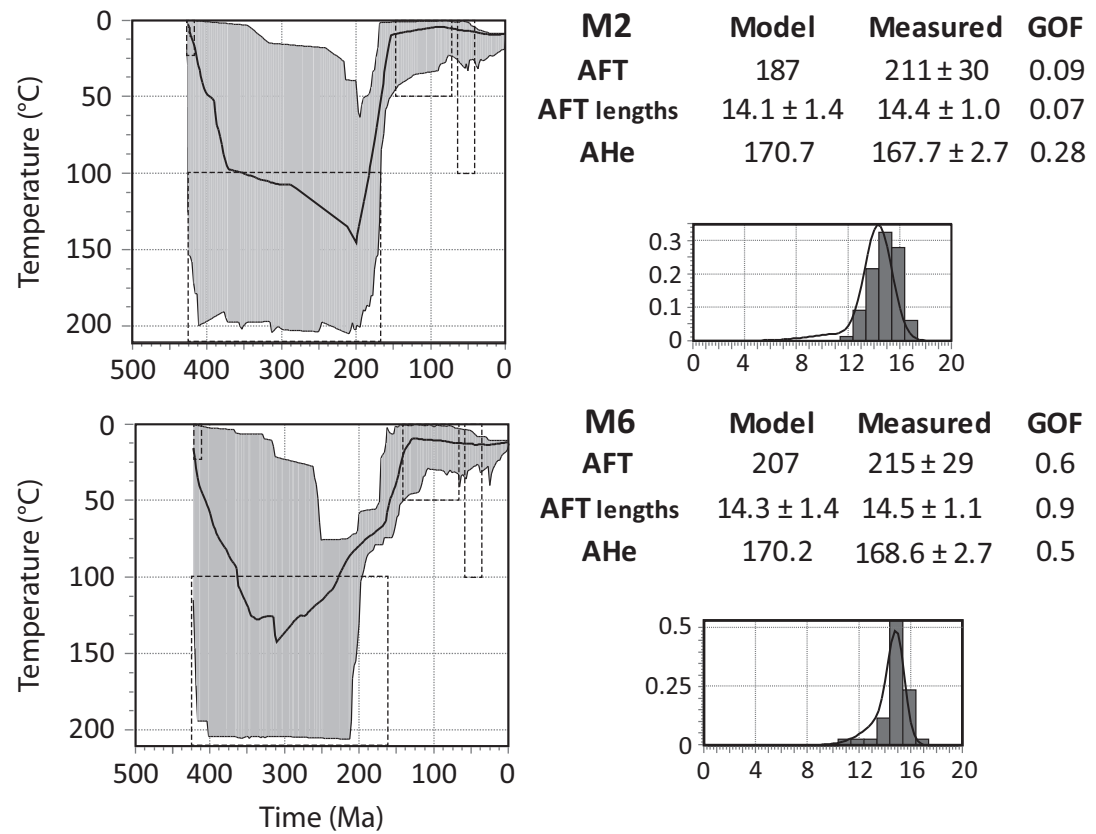

Fig. 8. Thermal evolution of the analysed samples obtained by thermal modelling with HeFTy (Ketcham, 2005). The software generates possible T-t paths using a Monte Carlo algorithm. Constraints are indicated by boxes bounded by dashed lines. The Goodness of Fit parameter (GOF) indicates the fit between measured and modelled data. The GOF and model values referred to the best fitting paths are shown in the tables on the right. Shaded areas mark envelopes of statistically acceptable (light grey, goodness-of-fit [GOF]: $0.05-0.5$ ) and good (dark grey, GOF $>0.5$ ) fit. Thick lines show the average thermal history with good fit. Track length histograms are shown on the right. Thermal histories are well defined only for the temperature interval of the AHe and AFT PRZ, and thus segments of the thermal path out of the range of the AHe and AFT PRZ are highly inferential.

temperature of ca. $10^{\circ} \mathrm{C}$ and geothermal gradients between 40 and $20^{\circ} \mathrm{C} \mathrm{km}^{-2}$, post-Jurassic burial must have been lower than ca. $2 \mathrm{~km}$.

\section{Burial modelling}

Thermal maturity and thermochronological data were used to reconstruct the burial and exhumation history of the sedimentary successions outcropping along the
Dniestr River (Figs 9, 10 and 11). The burial history of the succession of pseudo-well 1 begins with the deposition of about $50 \mathrm{~m}$ of siltstones during the Ordovician (since about $460 \mathrm{My}$ ). At that time, the Podolia basin was characterised by extremely low sedimentation rates, as confirmed by the paraconformity between Ordovician and Llandoverian units. Shallow water conditions developed during the Silurian, with the deposition of about $220 \mathrm{~m}$ of platform carbonates, nodular limestones and 


\section{A. Schito et al.}

(a)

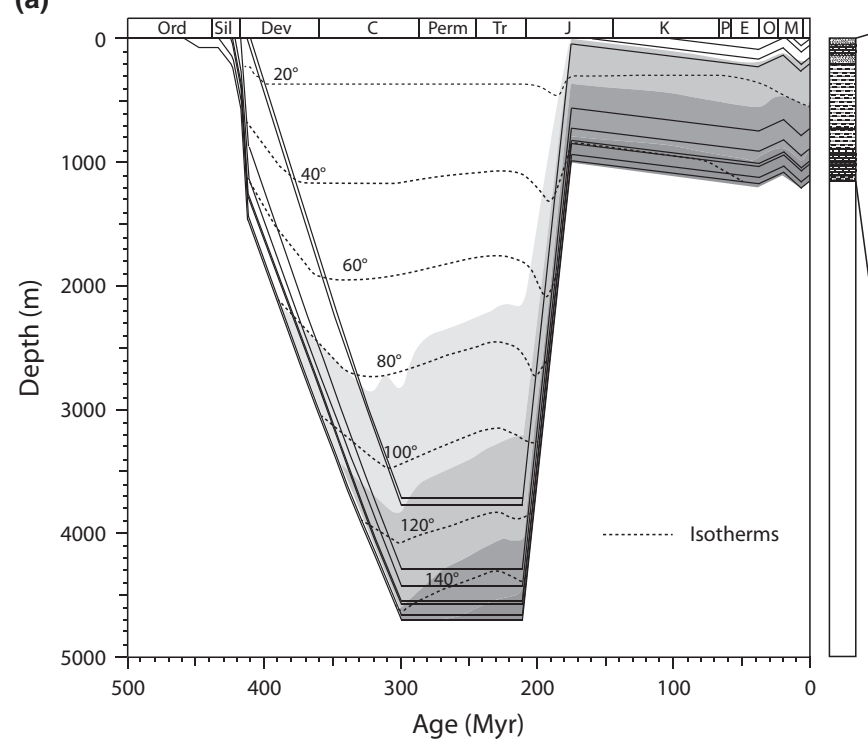

(b)

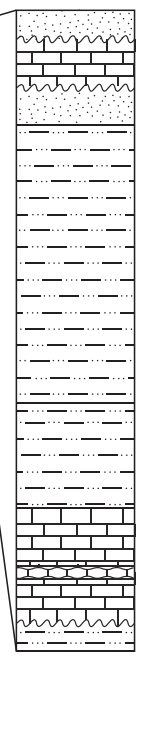

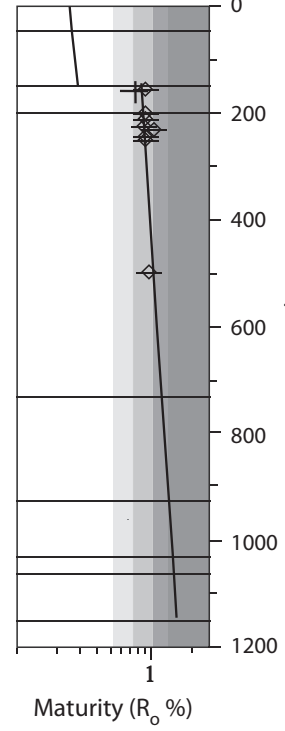

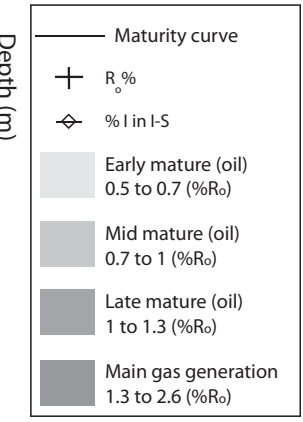

1.3 to $2.6\left(\% R_{0}\right)$

Fig. 9. (a) $1 \mathrm{D}$ burial and thermal history for pseudo-well 1 . The model is calibrated against illite content in mixed-layers I-S and reflectance data of Devonian rocks. (b) Present-day maturity data plotted against calculated maturity curves.

(a)

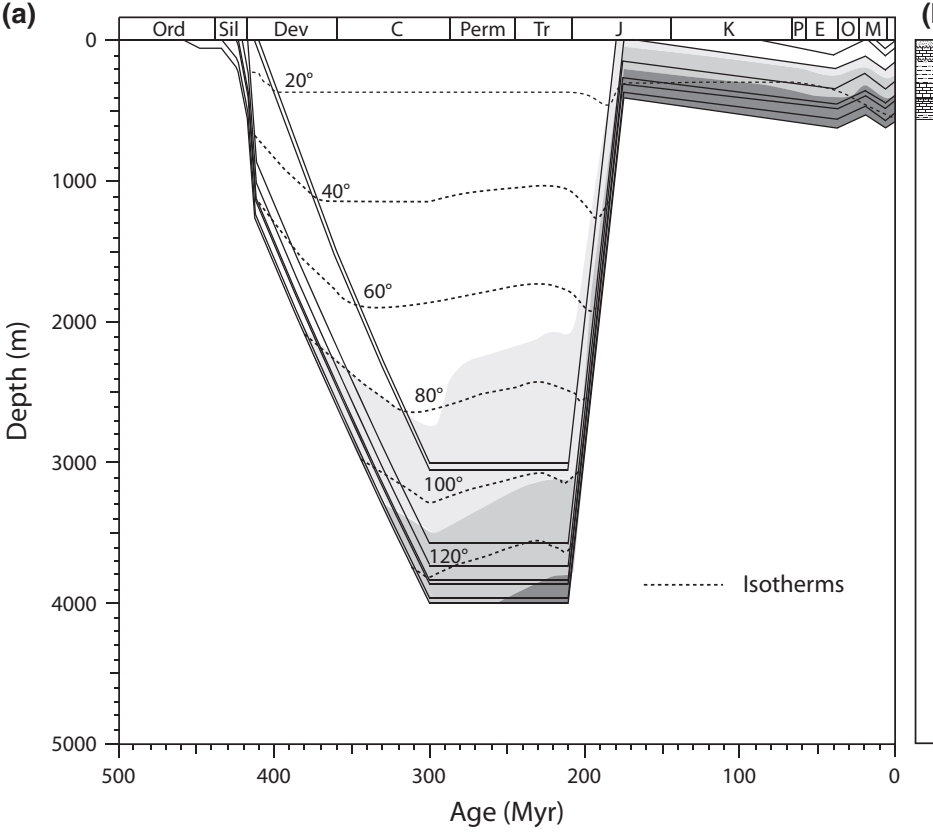

(b)
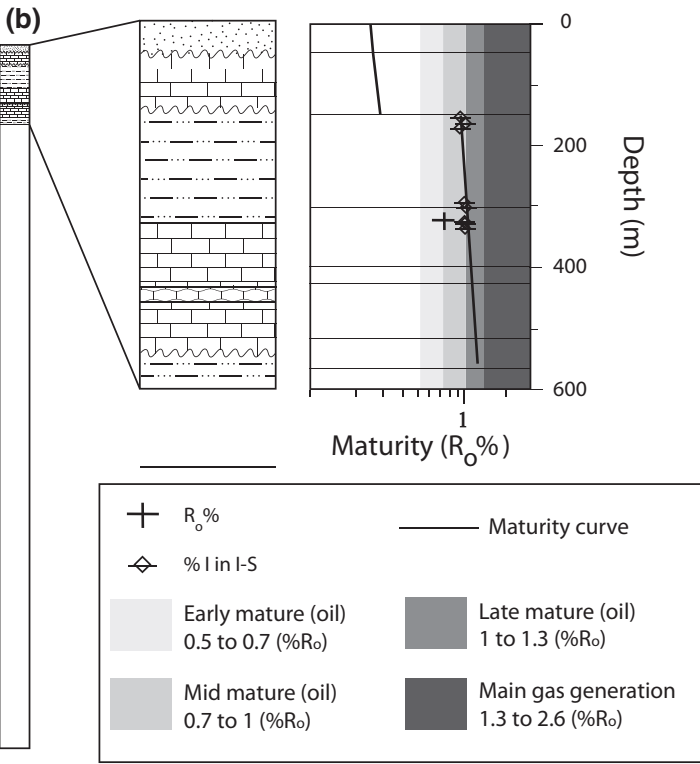

Fig. 10. (a) $1 \mathrm{D}$ burial and thermal history for pseudo-well 2. The model is calibrated against illite content in mixed-layers I-S and reflectance data of Ludlow-Pridoli rocks. (b) Present-day maturity data plotted against calculated maturity curves.

dolostones. Since the late Silurian and during the early Devonian, sedimentation of about $530 \mathrm{~m}$ of siltstones took place in deeper water marine environments. In the Pragian, the sector evolved from inshore lagoon to fluvial estuarine environments (Wrona \& Lis, 2012) with the deposition of the Old Red Sandstones (Dniestr formation). The basin deepened during the Carboniferous as a result of subsidence, hosting a large infill of sediments (about $3700 \mathrm{~m}$ ) until about $300 \mathrm{My}$ ago. At that time, the succession experienced maximum burial at depths of about $4700 \mathrm{~m}$ (Fig. 9a) and maximum temperatures at about 220 My (Fig. 12a). After nearly 100 My of scarce to null sedimentation following maximum burial, a Late Triassic-Early Jurassic exhumation event brought the Paleozoic rocks close to the surface, eroding the Carboniferous rocks. From Middle Jurassic onwards, a few hundred meters of carbonates were deposited, (Gutowski et al., 2010). Sedimentation continued until the end of the Eocene, when a new phase of exhumation occurred, recorded by the unconformity occurring at the base of the Miocene sediments capping the succession. The described evolution allows an acceptable calibration 
(a)

(a)

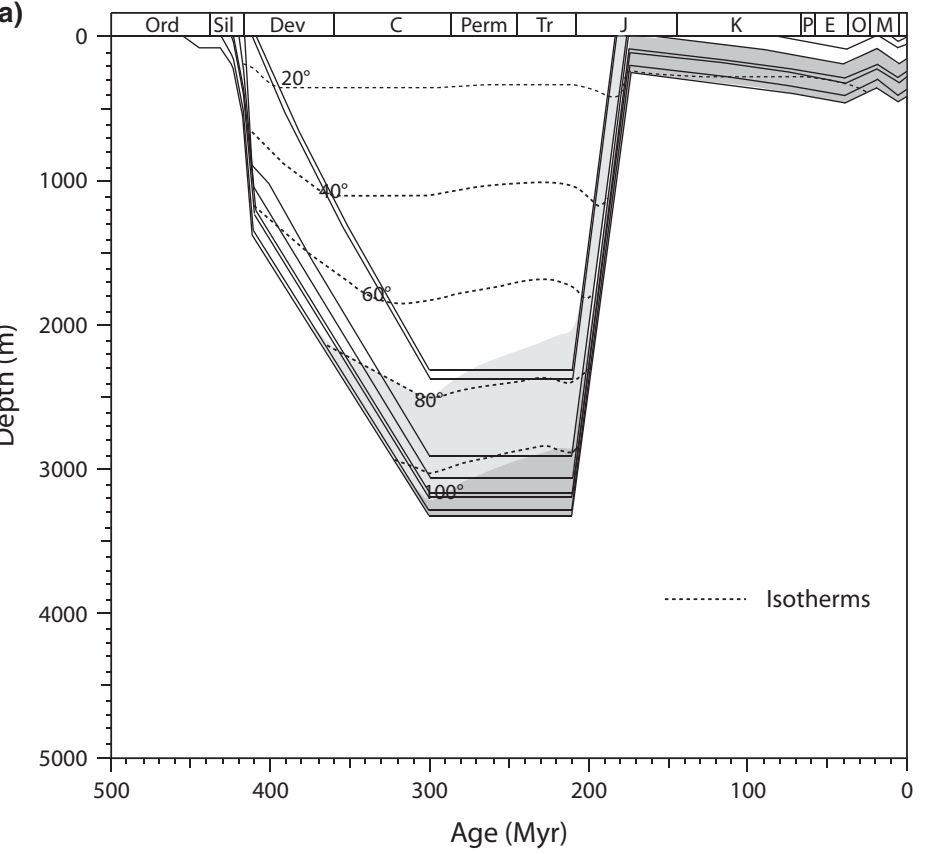

(b)

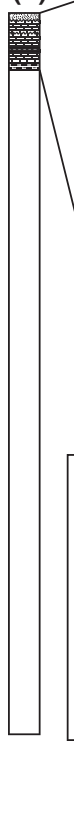

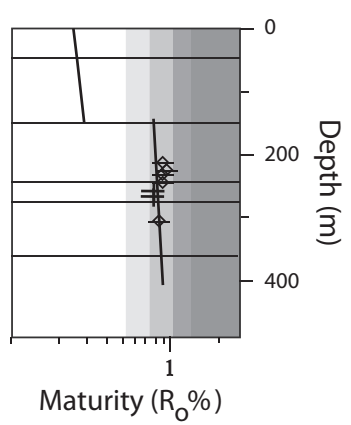

$+\mathrm{R}_{\mathrm{o}} \%$ Maturity curve

$\diamond \%$ in l-S

Early mature (oil) 0.5 to 0.7 (\%Ro)

Mid mature (oil) 0.7 to 1 (\% Ro)
Late mature (oil) 1 to $1.3\left(\% R_{0}\right)$

Main gas generation 1.3 to 2.6 (\% $R_{0}$ )

Fig. 11. (a) $1 \mathrm{D}$ burial and thermal history for pseudo-well 3. The model is calibrated against illite content in mixed-layer I-S and reflectance data of Llandoverian-Wenlockian rocks. (b) Present-day maturity data plotted against calculated maturity curves.

(a)

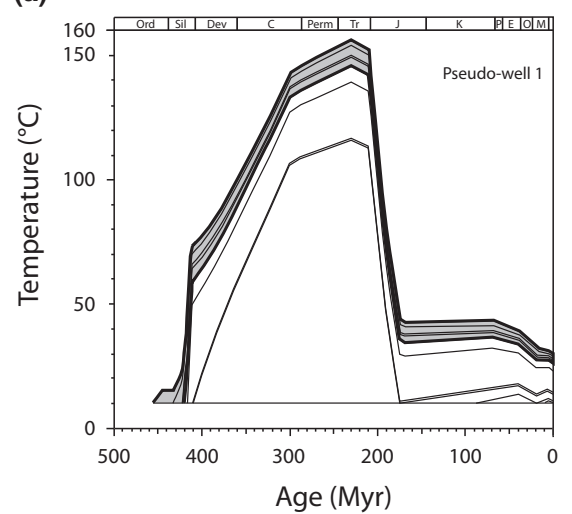

(b)

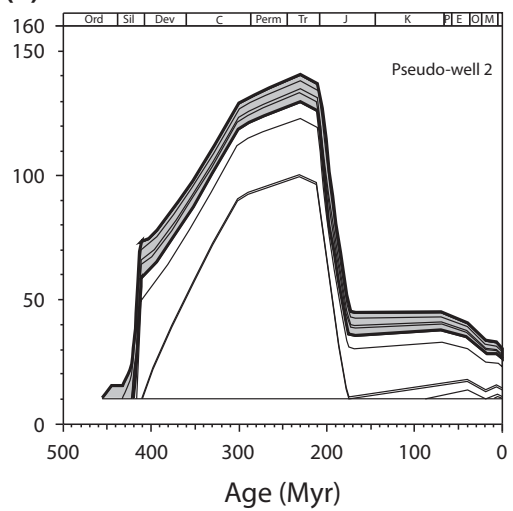

(c)

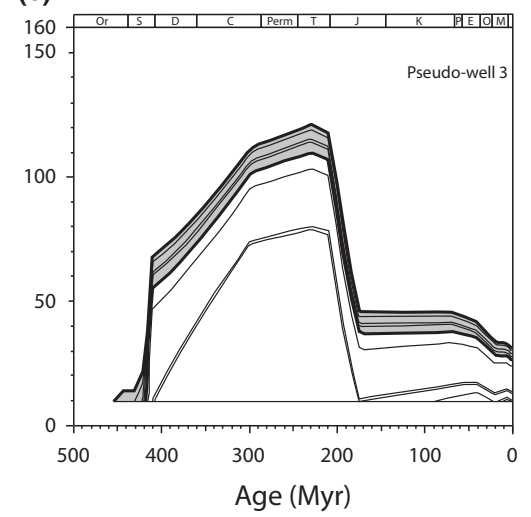

Fig. 12. Time-temperature diagrams of the lower Silurian interval for pseudo-well 1 (a), pseudo-well 2 (b) and pseudo-well 3 (c). The lines that delimit the lower Silurian rocks correspond to the temperature evolution of the top (line at lower temperature) and at the bottom (line at higher temperature).

against measured data, as shown by the present-day maturity curve of Fig. $9 b$.

The burial reconstructions of pseudo-wells 2 and 3 differ from that of pseudo-well 1 for the thickness of the Carboniferous infill and the amount of exhumation since Triassic times. The amount of eroded thickness obtained from the numerical models decreases moving towards the EEC and is about $3600 \mathrm{~m}$ for pseudo-well 2 and $3100 \mathrm{~m}$ for pseudo-well 3 (Figs 10 and 11). These differences affect the maximum temperatures experienced by the Lower Silurian and Ordovician successions. These are about $120{ }^{\circ} \mathrm{C}$ in pseudo-well 3, $140{ }^{\circ} \mathrm{C}$ in pseudo-well 2 and $155^{\circ} \mathrm{C}$ for pseudo-well 1 (Fig. 12). During the Triassic a rapid cooling occurred; a new temperature increase marked the last phase of burial during Jurassic and Cretaceous times. A gentle temperature decrease is recorded by the pre-Devonian units (Fig. 12) between 70 and $40 \mathrm{My}$ as a result of quicker rates of isotherm depression in comparison to burial rates. A Tertiary to present day general cooling, only slightly interrupted by a minor heating event associated with Miocene deposition, marks the youngest exhumation in the study area.

\section{DISCUSSION}

\section{Maximum Burial estimate}

The three representative pseudo-wells of Fig. 4, that were calibrated against organic and inorganic thermal 


\section{A. Schito et al.}

indicators, effectively summarise the burial history of the Podolia basin, where a Mesozoic regional unconformity covers progressively younger and thicker Paleozoic successions moving from the EEC to the west. Paleothermal data from Devonian and Silurian intervals indicate a mid-mature stage of $\mathrm{HC}$ generation (mainly $0.7-0.9 \mathrm{R}_{\mathrm{o}} \mathrm{eq}$ $\%$ and $82-90 \%$ illite content in mixed layers I-S), highlighting lateral variations of thermal maturity through time. Assuming heat flow changes through time similar to those reconstructed in nearby areas (e.g. for the Lublin basin; Botor et al., 2002; Poprawa et al., 2005; Carozzo et al., 2012), time-temperature diagrams for pseudo-well 1 and 2 indicate maximum palaeotemperatures between $110{ }^{\circ} \mathrm{C}$ and $155^{\circ} \mathrm{C}$ for the Silurian and Devonian successions (Fig. 12a,b) consistent with AFT total reset temperature (ca. $120^{\circ} \mathrm{C}$ ). On the other hand, the timetemperature diagram for Middle and Lower Silurian rocks in pseudo-well 3 (Fig. 12c) shows lower palaeotemperatures according to clay minerals and organic data.

A number of studies on the thermal evolution of sediments, based mainly on conodont alteration index (CAI), clay minerals and vitrinite reflectance have been already performed along the Peri Tornquist margin (Drygant, 1993; Nehring-Lefeld et al., 1997; Środoń et al., 2013). Our thermal maturity data are consistent with those derived from Drygant's zonation (1993) based on Conodont Alteration Index (CAI). In this paper, Silurian and Devonian successions of the Podolia Basin can be grouped in the 2-3 CAI zones corresponding to about $110-140{ }^{\circ} \mathrm{C}$ according to Epstein et al. (1977). These results are consistent with many geological studies used to build burial models (Drygant, 1993; Skompski et al., 2008; Małkowski et al., 2009; Kaljo et al., 2012; Olszewska-Nejbert \& Świerczewska-Gładysz, 2012; Racki et al., 2012; Wrona \& Lis, 2012) that point to a burial of 4-5 km during Paleozoic times. On the other hand, thermal maturity and palaeotemperature estimates have been recently reviewed by Środoń et al. (2013). The authors detected an illite content in mixed layers illite-smectite between 81 and $99 \%$, indicating deep diagenetic conditions, slightly higher with respect to our results and zonation. Moreover, they suggest a maximum burial of 5-10 km and related maximum palaeotemperatures of about $200{ }^{\circ} \mathrm{C}$, whereas our reconstruction indicates burial depths between 3.5 and $4.7 \mathrm{~km}$ and derived maximum palaeotemperatures between 110 and $155^{\circ} \mathrm{C}$. This significant discrepancy between the two proposed thermal scenarios depends on the choice of thermal boundary conditions. In our reconstruction, heat flow varies through time with values of $50 \mathrm{~mW} \mathrm{~m}^{-2}$ in Paleozoic and Mesozoic times, $65 \mathrm{~mW} \mathrm{~m}^{-2}$ in the Carboniferous (Botor et al., 2002; Poprawa et al., 2005 and Carozzo et al., 2012), and $30 \mathrm{~mW} \mathrm{~m}^{-2}$ during the Cenozoic till the present-day. On the other hand, Środoń et al. (2013) applied a simplified thermal model with a constant geothermal gradient of $20-40{ }^{\circ} \mathrm{C} \mathrm{km}{ }^{-2}$. Furthermore, the numerical models performed in this work allow us to outline the Podolia basin as an asymmetric Paleozoic trough in which sediment accommodation space decreased progressively towards the EEC. This is at variance with the uniform burial throughout the basin suggested by Środon et al. (2013).

\section{The late Triassic-Early Jurassic exhumation}

Thermochronometric ages indicate that Paleozoic sediments were exhumed close to the surface in the Late Triassic-Early Jurassic (Fig. 8). These data match with the age of the oldest sediments overlapping the widespread unconformity along the margin of the Ukrainian Shield. However, our AFT ages differ significantly from those obtained by Środoń et al. (2013). These authors reported ages spanning from 63 to $107 \mathrm{My}$, in some cases with a large spread among grains of the same sample. Also track lengths differ from our measurements, as all of theirs are shorter than our mean lengths and have a larger standard deviation. As a consequence, Środoń et al. (2013) indicate an exhumation event during the Cretaceous, followed by a heating event characterised by temperatures of about $100{ }^{\circ} \mathrm{C}$. However, robust evidence confirms the reliability of our dataset. First of all, there is an internal consistency among our AFT data, with very similar central ages (taking into account the analytical error) and between AFT ages and AHe minimum ages. Furthermore, the cooling event unravelled by our modelling is fully compatible with the widespread unconformity, above which Jurassic sediments were deposited. On the other hand, the model presented by Środoń et al. (2013) implies about $3 \mathrm{~km}$ of burial during the Late Cretaceous, which does not find any geological evidence in the study region. Moreover, our AHe analysis displayed Middle Jurassic minimum ages. This feature rules out a post-Cretaceous heating event with temperatures of ca. $100{ }^{\circ} \mathrm{C}$, which would have caused the total reset of the AHe system. Our high quality, integrated thermochronological datasets strongly support the hypothesis of a Late Triassic-Early Jurassic major cooling event. All single grain ages (both AFT and AHe) are plotted in Fig. 6. Most of them fit well with the age of the Cimmerian orogeny, whereas both older (Variscan) and younger (Alpine) ages are poorly represented in the thermochronological dataset.

Our burial models (Figs 9, 10 and 11) depict a major exhumation event during the Late Triassic-Early Jurassic. The Alpine exhumation event, testified by the regional unconformity between Cretaceous and Miocene sediments, must have been moderate, because it has not been recorded by the AHe thermochronometer, that is, sensitive to very low temperatures (Tc of ca. $60{ }^{\circ} \mathrm{C}$ ). As no major low angle normal faults that could have produced tectonic exhumation are present in this area, we suggest that the vertical displacement leading to about $3-4 \mathrm{~km}$ of erosion and unroofing during the Triassic-Early Jurassic could be related to far-field tectonic effects related to the Cimmerian collision, in an area, where lithosphere strength contrasts occur along the Trans European Suture Zone. Spatial and temporal 
strength variations of the lithosphere control far field tectonic stresses that can propagate at distances of many hundreds of kilometres from the orogen (Ziegler et al., 1995; Dickerson, 2003). Examples can be found in the deformation at the northern margin of the Tibetan Plateau, which was synchronous with the early stage of India-Asia collision (e.g. Yin et al., 2008; Clark et al., 2010), in the southeastern Black Sea region, where Neogene deformation is linked to far-field effects of the Arabia-Eurasia indentation (Albino et al., 2014), and even in subduction settings such as the retroarc foreland region of the Patagonian Andes (e.g. Savignano et al., 2016).

\section{CONCLUSIONS}

The integration of paleothermal indicators, thermochronological data and stratigraphic constraints allowed us to model the burial-exhumation history of the Paleozoic successions exposed along the western border of the Ukrainian Shield, providing valuable information on the tectonic history of this area. First, we defined the amount of maximum burial (ca. $4-5 \mathrm{~km}$ ) that the Paleozoic succession underwent during Carboniferous times. Second, we dated the exhumation through the $120-40{ }^{\circ} \mathrm{C}$ temperature range to the Late Triassic-Early Jurassic. The recognition of this previously undetected exhumation event represents a very interesting and somehow unexpected result, as it is not linked to the Variscan orogeny and nor to the Alpine one. In particular, it is worth of note that no major effect on the burial and exhumation history of this region was induced by the Alpine cycle, whose collisional front is located $<100 \mathrm{~km}$ from the western border of the Ukrainian Shield. On the other hand, the unravelled Late Triassic-Early Jurassic exhumation event is coeval with the Cimmerian collision. Therefore, despite the fact that the margin of the East European Craton is located several hundreds of kilometres away from the Cimmerian orogen, the new datasets provided in this study suggest that Mesozoic exhumation in the Podolia region occurred as a response to far field stress propagation associated with the Cimmerian collision. This shows how the burial history of a basin located on a plate margin can, in some instances, not be directly related to its distance from the collisional fronts located along the margin itself.

\section{ACKNOWLEDGEMENTS}

We thank professor W. Huff of the University of Cincinnati for kindly providing the bentonite samples. Thoughtful and constructive reviews by Basin Research referee Matthias Bernet and the useful comments by Editor Andreas Mulch are gratefully acknowledged. This research was funded by MIUR grants to Roma Tre PhD School in Earth Sciences (XXVIII doctoral cycle).

\section{REFERENCES}

Albino, I., Cavazza, W., Zattin, M., Okay, A.I., Adamia, S. \& SADRADZE, N. (2014) Far-field tectonic effects of the ArabiaEurasia collision and the inception of the North Anatolian Fault system. Geol. Mag., 151(02), 372-379.

Aldega, L., Corrado, S., Grasso, M. \& Maniscalco, R. (2007) Correlation of diagenetic data from organic and inorganic studies in the Apenninic-Maghrebian fold-and-thrust belt: a case study from Eastern Sicily. 7. Geol., 115(3), 335353.

Aldega, L., Corrado, S., di Paolo, L., Somma, R., ManisCAlCO, R. \& Balestrieri, R. (2011) Shallow burial and exhumation of the Peloritani Mts. (NE Sicily, Italy): insight from paleo-thermal and structural indicators. Geol. Soc. Am. Bull., 123, 132-149.

Bertrand, R. \& Malo, M. (2012) Dispersed organic matter reflectance and thermal maturation in four hydrocarbon exploration wells in the Hudson Bay Basin: regional implications. Geol. Surv. Canada, Open File, 7066, 54.

Botor, D., Kotarba, M. \& Kosakowski, P. (2002) Petroleum generation in the Carboniferous strata of the Lublin Trough (Poland): an integrated geochemical and numerical modelling approach. Org. Geochem., 33, 461-476.

Braun, J., van der Beek, P. \& Batt, G. (2006) Quantitative Thermochronology: Numerical Methods for the Interpretation of Thermochronological Data. Cambridge University Press, Cambridge, NY.

Bula, Z. \& Habryn, R. (2011) Precambrian and Palaeozoic basement of the Carpathian Foredeep and the adjacent Outer Carpathians (SE Poland and western Ukraine). Ann. Soc. Geol. Pol., 81, 221-239.

Burnham, A.K. \& Sweeney, J.J. (1989) A chemical kinetic model of vitrinite maturation and reflectance. Geochim. Cosmochim. Acta, 53(10), 2649-2657.

Bustin, R.M., Barnes, M.A. \& Barnes, W.C. (1990) Determining levels of organic diagenesis in sediments and fossil fuels. Diagenesis Geol. Assoc. Canada, 4, 205-226.

Butler, R.W.H. (1992) Hydrocarbon maturation, migration and tectonic loading in the western Alps. (Ed. by England W.A. \& Fleet A.J.) Petrol. Migration Geol. Soc. London Spec. Publi., 59, 227-244.

Caricchi, C., Aldega, L., Barchi, M., Corrado, S., Grigo, D., Mirabella, F. \& Zattin, M. (2015) Exhumation patterns along shallow low-angle normal faults: an example from the Altotiberina active fault system (Northern Apennines, Italy). Terra Nova, 27 (4), 312-321.

Carlini, M., Artoni, A., Aldega, L., Balestrieri, M.L., Corrado, S., Vescovi, P., Bernini, M. \& Torelli, L. (2013) Exhumation and reshaping of far-travelled/allochthonous tectonic units in mountain belts. New insights for the relationships between shortening and coeval extension in the western Northern Apennines (Italy). Tectonophysics, 608, 267-287.

Carozzo, S., Corrado, S., Gaeta, F. \& Grigo, D. (2012) Thermal maturity distribution of dispersed organic matter in probable Silurian gas shale in the Baltzric and Lublin basins (Poland) by means of 3D Petroleum System modelling. AAPG Search and Discovery Article \#120098@2013 AAPG Hedberg Conference Petroleum Systems: Modelling the Past, Planning the Future, Nice, France, October 1-5, 2012. 
Castelluccio, A., Mazzoli, S., Andreucci, B., Jankowski, L., Szaniawski, R. \& Zattin, M. (2016) Building and exhumation of the Western Carpathians: new constraints from sequentially restored, balanced cross sections integrated with low-temperature thermochronometry. Tectonics, 35(11), 2698-2733.

Clark, M.K., Farley, K.A., Zheng, D., Wang, Z. \& Duvall, A.R. (2010) Early Cenozoic faulting of the northern Tibetan Plateau margin from apatite $(\mathrm{U}-\mathrm{Th}) / \mathrm{He}$ ages. Earth Planet. Sci. Lett., 296(1), 78-88.

Corrado, S., Aldega, L., Balestrieri, M.L., Maniscalco, R. \& Grasso, M. (2009) Structural evolution of the sedimetary accretionary wedge of the alpine system in Eastern Sicily: thermal and thermochronological constraints. Geol. Soc. Am. Bull., 121, 1475-1490.

Corrado, S., Invernizzi, C., Aldega, L., D’Errico, M., di Leo, P., Mazzoli, S. \& Zattin, M. (2010a) Testing the validity of organic and inorganic thermal indicators in different tectonic settings from continental subduction to collision: the case history of the Calabria-Lucania border (southern Apennines, Italy). 7. Geol. Soc., 167(5), 985-999.

Corrado, S., Aldega, L. \& Zattin, M. (2010b) Sedimentary vs. tectonic burial and exhumation along the Apennines (Italy). In: The Geology of Italy (Ed. by Beltrando M., Peccerillo A., Mattei M., Conticelli S. \& Doglioni C.) 7. Virt. Explor., 36, paper 15, 1-37.

DiCKERSON, P.W. (2003) Intraplate mountain building in response to continent-continent collision - the Ancestral Rocky Mountains (North America) and inferences drawn from the Tien Shan (Central Asia). Tectonophysics, 365(1), 129-142.

Djimbi, D.M., Gautheron, C., Roques, J., Tassan-Got, L., Gerin, C. \& Simoni, E. (2015) Impact of apatite chemical composition on (U-Th)/He thermochronometry: an atomistic point of view. Geochim. Cosmochim. Ac., 167, 162176 .

Donelick, R.A., O’Sullivan, P.B. \& Ketcham, R.A. (2005) Apatite fission-track analysis. Rev. Mineral. Geochem., 58(1), 49-94.

Drygant, D.M. (1993) Conodont colour as the indicator of the geological pro - cesses (Volyn - Podillia). Paleonto - logičeskij žurnal, 23, 35-37.

Drygant, D.M. (2000) Lower and middle paleozoic of the Volyn'- Podillya margin of the East - European Platform and Carpathian Foredeep. Naukovi zapysky Deržavnogo pryrodoznavс̌оgо тиzей, 15, 24-129.

DunKL, I. (2002) Trackkey: a Windows program for calculation and graphical presentation of fission track data. Comput. Geosci., 28 (1), 3-12.

Ehlers, T.A. \& Farley, K.A. (2003) Apatite (U-Th)/He thermochronometry: methods and applications to problems in tectonic and surface processes. Earth Planet. Sci. Lett., 206(1), $1-14$.

Epstein, A.G., Epstein, J.B. \& Harris, L.D. (1977) Conodont Color Alteration an Index to Organic Metamorphism. U.S. Geol. Survey Prof. Paper 995, 27 pp.

Flowers, R.M., Ketcham, R.A., Shuster, D.L. \& Farley, K.A. (2009) Apatite (U-Th)/He thermochronometry using a radiation damage accumulation and annealing model. Geochim. Cosmochim. Acta, 73(8), 2347-2365.

Galbraith, R.F. (1981) On statistical models for fission track counts. F. Int. Assoc. Math. Geol., 13(6), 471-478.
Gautheron, C., Tassan-Got, L., Barbarand, J. \& Pagel, M. (2009) Effect of alpha-damage annealing on apatite (U-Th)/ He thermochronology. Chem. Geol., 266 (3), 157-170.

Gleadow, A.J.W., Duddy, I.R., Green, P.F. \& Lovering, J.F. (1986) Confined fission track lengths in apatite: a diagnostic tool for thermal history analysis. Contrib. Mineral. Petrol., 94, $405-415$.

Gutowski, J., Popadyuk, I.V. \& Olszewska, B. (2010) Stratigraphy and facies development of the upper Tithonian-lower Berriasian Niżniów Formation along the Dnister River (Western Ukraine). Geol. Quart., 49 (1), 45-52.

Huff, W.D., Bergström, S.M. \& Kolata, D.R. (2000) Silurian K-bentonites of the Dniester Basin, Podolia, Ukraine. F. Geol. Soc., 157(2), 493-504.

HuRFord, A.J. (1990) Standardization of fission track dating calibration: recommendation by the Fission Track Working Group of the IUGS Subcommission on Geochronology. Chem. Geol. Isot. Geosci. Section, 80(2), 171-178.

Hurford, A.J. \& Green, P.F. (1983) The zeta age calibration of fission-track dating. Chem. Geol., 41, 285-317.

Invernizzi, C., Bigazzi, G., Corrado, S., di Leo, P., Schiattarella, M. \& Zattin, M. (2008) New thermobaric constraints on the exhumation history of the liguride accretionary wedge, Southern Italy. Ofioliti, 33(1), 21-32.

Kaljo, D., Martma, T., Grytsenko, V., Brazauskas, A. \& Kaminskas, D. (2012) Př́dolí carbon isotope trend and upper Silurian to lowermost Devonian chemostratigraphy based on sections in Podolia (Ukraine) and the East Baltic area. Estonian 7. Earth Sci., 61(3), 162.

Ketcham, R.A. (2005) Forward and inverse modelling of lowtemperature thermochronometry data. Rev. Mineral. Geochem., 58(1), 275-314.

Ketcham, R.A., Donelick, R.A. \& Carlson, W.D. (1999) Variability of apatite fission-track annealing kinetics. III. Extrapolation to geological time scales. Am. Mineral., 84, 1235-1255.

Ketcham, R.A., Carter, A.C., Donelick, R.A., Barbarand, J. \& Hurford, A.J. (2007) Improved modelling of fission-track annealing in apatite. Am. Mineral., 92, 799-810.

Kurovets, I.M. \& Koltun, Y.V. (2012) Depositional Environments of Prospective for Shale Gas Silurian Deposits of the East European Platform, Ukraine. In 74th EAGE Conference \& Exhibition.

Malkowski, K., Racki, G., Drygant, D. \& Szaniawski, H. (2009) Carbon isotope stratigraphy across the Silurian-Devonian transition in Podolia, Ukraine: evidence for a global biogeochemical perturbation. Geol. Mag., 146(5), 674-689.

Merriman, R.J. \& Frey, M. (1999) Patterns of very low-grade metamorphism in metapelitic rocks. In: Lomgrade Metamorphism (Ed. by M. Frey \& D. Robinson), pp. 61-107. Blackwell, Oxford.

Merryman, R.J. \& Frey, M. (1999) Patterns of very low-grade metamorphism in metapelitic rocks. Lom-grade Metamorphism, 61-107.

Mod, B. 1-D for WindowsTM (1996) A Basin Analysis Modelling System version. 5, 386 .

Moore, D.M. \& ReYNolds, R.C.J.R. (1997) X-Ray Diffraction and the Identification and Analysis of Clay Minerals. Oxford University Press, Oxford.

Nehring-Lefeld, M., Modliński, Z. \& Swadowska, E. (1997) Thermal evolution of the Ordovician in the western margin of the East-European Platform: CAl and Ro data. Geol. Q., 41 (2), 129-138. 
Olszewska-Nejbert, D. \& Świerczewska-Gladysz, E. (2012) Facies and sedimentation of Coniacian deposits of the Kraków Swell in the Wielkanoc area (southern Poland). Geol. Q., 57 (1), 1-16.

ONCKEN, O. (1982) Basin reconstruction by coalification studies. Geol. Rundsch., 71, 579-602.

di Paolo, L., Olivetti, V., Corrado, S., Aldega, L., BalestriERI, M.L. \& Maniscalco, R. (2014) Detecting the stepwise propagation of the Eastern Sicily thrust belt (Italy): insight from thermal and thermochronologic constraints. Terra Nova, 26(5), 363-371.

Poprawa, P., Żywiecki, M. \& Grotek, I. (2005) Burial and thermal history of the Holy Cross Mts. area-preliminary results maturity Model. Polskie Tomarzystmo Mineralogiczne, 26, 251-254.

Racki, G., Baliński, A., Wrona, R., MaŁkowski, K., Drygant, D. \& Szaniawski, H. (2012) Faunal dynamics across the silurian-devonian positive isotope excursions $(\delta 13 \mathrm{C}, \delta 18 \mathrm{O})$ in Podolia, Ukraine: comparative Analysis of the Ireviken and Klonk Events. Acta Palaeontol. Pol., 57(4), 795-832.

ReInERs, P.W. \& Brandon, M.T. (2006) Using thermochronology to understand orogenic erosion. Annu. Rev. Earth Planet. Sci., 34, 419-466.

Reiners, P.W., Thomson, S.N., McPhillips, D., Donelick, R.A. \& Roering, J.J. (2007) Wildfire thermochronology and the fate and transport of apatite in hillslope and fluvial environments. F. Geophys. Res., series, 112, F04001, doi:10.1029/ 2007JF000759.

SAChSEnhofer, R.F. \& Koltun, Y.V. (2012) Black shales in Ukraine-A review. Mar. Pet. Geol., 31(1), 125-136.

Savignano, E., Mazzoli, S., Arce, M., Franchini, M., Gautheron, C., Paolini, M. \& Zattin, M. (2016) (Un)Coupled thrust belt-foreland deformation in the northern Patagonian Andes: new insights from the Esquel-Gastre sector $\left(41^{\circ} 30^{\prime}-\right.$ $43^{\circ} \mathrm{S}$ ). Tectonics, 35, 2636-2656.

Schito, A., Corrado, S., Aldega, L. \& Grigo, D. (2016) Overcoming pitfalls of vitrinite reflectance measurements in the assessment of thermal maturity: the case history of the lower Congo basin. Mar. Pet. Geol., 74, 59-70.

Sclater, J.G. \& Christie, P. (1980) Continental stretching: an explanation of the post-mid-cretaceous subsidence of the central North Sea basin. 7. Geophys. Res. Solid Earth (19782012), 85 (B7), 3711-3739.

Shuster, D.L., Flowers, R.M. \& Farley, K.A. (2006) The influence of natural radiation damage on helium diffusion kinetics in apatite. Earth Planet. Sci. Lett., 249 (3), 148-161.

Skompski, S., Łuczyński, P., Drygant, D. \& KozŁowski, W. (2008) High-energy sedimentary events in lagoonal successions of the Upper Silurian of Podolia, Ukraine. Facies, 54(2), 277-296.

Środoń, J., Paszkowski, M., Drygant, D., Anczkiewicz, A. \& BANAŚ, M. (2013) Thermal history of lower paleozoic rocks on the peri-tornquist margin of the East European Craton (Podolia, Ukraine) inferred from combined XRD, K-Ar, and AFT Data. Clays Clay Miner., 61(2), 107-17732.

Sweeney, J.J. \& Burnham, A.K. (1990) Evaluation of a simple model of vitrinite reflectance based on chemical kinetics (1). AAPG Bull., 74(10), 1559-1570.

Wrona, R. \& Lis, P. (2012) Silurian succession within the Lower Paleozoic Basin of Podolia. In: Geoshale 2012, Recent Advances in Geology of Fine-Grained Sediments, FieldtripGuidebook, pp. 255-259. Warsaw, Poland.

Yin, A., Dang, Y.Q., Wang, L.C., JiAng, W.M., Zhou, S.P., Chen, X.H. \& McRivette, M.W. (2008) Cenozoic tectonic evolution of Qaidam basin and its surrounding regions (Part 1): the southern Qilian Shan-Nan Shan thrust belt and northern Qaidam basin. Geol. Soc. Am. Bull., 120(7-8), 813-846.

Ziegler, P.A., Cloetingh, S. \& van Wees, J.D. (1995) Dynamics of intra-plate compressional deformation: the Alpine foreland and other examples. Tectonophysics, 252(1), 7-59.

Manuscript received 8 Fanuary 2015; In revised form 22 December 2016; Manuscript accepted 1 February 2017. 